\title{
変位の絶対値に比例する摩擦力を生成する 摺動型減衰装置に関する研究
}

\author{
片山 拓朗 1 - 山尾 敏孝2 \\ 1正会員 崇城大学教授 工学部エコデザイン学科（テ860-0082 熊本市池田4-22-1） \\ Email: katayama@eco.sojo-u.ac.jp \\ 2 フェロー 熊本大学教授 大学院自然科学研究科（†860-8555 熊本市黒髪2-39-1) \\ Email: tyamao@kumamoto-u.ac.jp
}

\begin{abstract}
本論文では, 構造物のパッシブ振動制御に資する, 減衰力としての摩擦力が変位の絶対值に比例して増 加する摺動型減衰装置を提案する。提案の装置は凹型・凸型摺動体，U型板ばねおよび支持はりで構成す る．凹型・凸型摺動体は，作動方向に僅かに傾いた二組の前方用摺動面とそれらと逆の傾きの一組の後方 用摺動面を有し，凹型・凸型摺動体の摺動変位の絶対值に比例して高さが増加する. 支持はりとU型板ば ねは型・凸型摺動体の高さの変化を利用して摺動面に圧縮力を作用させる．提案の装置はこの圧縮力を 利用して変位の絶対值に比例して増加する摩擦力を生成する. 提案の装置の基本構造と摩擦力を生成する 原理が述べられ, 装置を装着した一層ラーメンの静的力学特性が理論的に説明される. その静的力学特性 は模型を用いた載荷試験の結果と良く対応した.
\end{abstract}

Key Words : frictional force, rubbing displacement, rubbing damper device, rubbing pair of concave and convex bars, U-type leaf spring, simple rigid frame

\section{1. はじめに}

関東平野，濃尾平野および大阪平野に位置する 2〜8 秒の水平固有周期を持つ構造物は, 南海地震や東南海地 震などの海溝型地震によって引き起こされると予想され る, やや長周期の地震動との共振を引き起こす可能性が 高い ${ }^{1)}$. そのような既設・新設の構造物に設置が可能で, 長周期と大振幅に対応できる制震効果の高い 減衰装置の 開発は急務と考えられる.

構造物の振動を抑制するパッシブ型減衰装置を力と変 位の履歷曲線の特徵で分類すると, 粘性型, 塑性型およ び摩擦型などに分けられる ${ }^{2), 33}$. 粘性型は，一般に減衰 力が対象物の応答速度に比例するので, 長周期構造物で 所要の減衰定数を得るためには, 短周期構造物の場合に 比べて減衰装置が大型・高性能化し設置費用が増大寸る 問題がある，高性能の粘性型減衰装置としては，例えば 増幅機構付き減衰装置が実用化されている ${ }^{4)}$, 5). 塑性型 は，一般に弾性体と塑性体の両方の力学特性を有してい るので，減衰装置が弾性体として作動する小振幅時には 等価粘性減衰係数が小さく, 完全塑性体として作動する 大振幅時には振幅増加に対して等価粘性減衰係数が減少 する問題がある，塑性型減衰装置としては，例えば座屈
拘束ブレースが中・高層ビルで広く使用されており 9, また，アーチ橋の耐震性向上策としてその適用が検討さ れている ${ }^{7), 8)}$. 摩擦型は, 一般に摩擦力の大きさが変位 に拘わらず一定なので，小振幅時にはすべり面の固着に より機能が発揮されず，大振幅時には振幅の増加に対し て等価粘性減衰係数が減少するなどの問題がある. 摩擦 型減衰装置としては, 安定で大きな摩擦力を生成する複 数摺動面を有する摩擦型ダンパー9'が開発され，大きな 摩擦係数が得られるアルミニューム合金板を用いた摩擦 ダンパー10),11)が提案されている.

ここで, 摩擦型減衰装置は対象構造物の固有周期の長 周期化に伴う応答速度の低下によって減衰力が低下しな いことに着目すると，振幅の増加に対して等価粘性減衰 係数が減少しないような機能を摩擦型減衰装置に付加す ることができれば，長周期の構造物に対して，小振幅か ら大振幅までの振動エネルギーを効率的に吸収できる減 衰装置を実現できると考えられる，例えば，減衰力とし ての摩擦力を変位の絶対值に比例して増加させることが できれば, Clough and Penzien が示した履歴减衰 ${ }^{12)}$ の特 性を有する減衰装置すなわち構造物の振幅の増加に対し て等価粘性減衰係数が減少しない摩擦型減衰装置を実現 できると考えられる。しかし，文献 12)では，そのよう 
な履歴減衰を実現する具体的な装置や力学モデルは言及 されていない.

Tadjbakhsh and $\operatorname{Lin}^{13}$ は, 免震建物に対して，建物に連 結した摩擦板と基礎に連結した摩擦板からなる減衰装置 を提案している，その装置では，建物に固定された摩擦 板の内, 外側の摩擦板同士をタイで連結し, さらにタイ と基礎をケーブルで連結させることにより，変位に比例 する摩擦力すなわち減衰力を発生させる. しかし，この 装置は免震構造などの大きな変位に対応できるが，建物 の階層間の小さな水平相対変位などを対象とする場合は 一考を要すると考えられる.

若林らは二組の V 型リンク機構を用いた摩擦型減衰 装置を提案している ${ }^{14)}$. この装置は，原点復帰特性を 持つ漸硬型摩擦力特性, 寸なわち線形の復元力に, 変位 に比例する摩擦力を付加した力学特性を有する. しかし, 摩擦力を生成する機構がやや複雑であり, 多数の減衰装 置を必要とする大型構造物への適用にあたってはコスト 面で問題があると考えられる。

本論文では，長周期の構造物において，小振幅から大 振幅までの振動エネルギーを効率的に吸収できる減衰装 置を開発するために, 減衰力としての摩擦力が変位の絶 対值に比例して増加する力学特性を有し, 回型摺動体, 凸型摺動体，U 型板ばねおよび支持はりで構成する摺動 型減衰装置を提案する. 凹型摺動体と凸型摺動体は，そ れぞれが減衰装置の作動方向に僅かに傾いた二つの前方 用摺動面と，それらと傾きが逆となる一つの後方用摺動 面を有し，前方用摺動面同士および後方用摺動面同士が 対面かつ接触するように組み立てられる。組み立てられ た凹型・凸型摺動体は，作動方向の摺動面の傾きのため に，作動方向に平行な凹型摺動体と凸型摺動体の相対変 位の絶対值に比例して高さが増加する. 本論文ではこの 凹型摺動体と凸型摺動体の相対変位を摺動変位と呼ぶ. 凸型摺動体を支持し，支持はりを介して構造物に直接的 または間接的に固定される U 型板ばねは，四型・凸型 摺動体の高さの変化を利用して, 几型・凸型摺動体に圧 縮力を作用させる． 提案の減衰装置はこの圧縮力を利 用して摺動変位の絶対值に比例して大きさが増加する摩 擦力を凹型・凸型摺動体の摺動面に発生させる.この摩 擦力が構造物の振動を抑制する減衰力となる. 提案の減 衰装置における摩擦力を生成する機構は前述の若林らの 機構と明らかに異なる。

また，凹型・凸型摺動体の高さの変化が抑制されるよ うに，且つ減衰装置の作動方向が構造物内の相対変位の 主たる方向と平行となるように，凹型摺動体と支持はり は直接にあるいは部材などを介して間接に構造物に固定 される. 回型・凸型摺動体の高さの変化を抑制すること と, 減衰装置の作動方向を構造物内の相対変位の主たる 方向と平行にすることが提案の減衰装置の構造物に対す
る装着条件である.これらの装着条件を満たすことがで きれば，ラーメンやアーチなどの構造形式に拘わらずに， 提案の減衰装置はあらゆる構造物に適用できると考えら れる.

先ず，提案の摺衰装置の基本構造を説明する. 次に, 摺動変位の絶対值に比例して大きさが増加する摩擦力を 生成する原理をローラで支持された減衰装置で説明し, この減衰装置の水平力と摺動変位の関係式および等価粘 性減衰係数を理論的に導く. 次に, 減衰装置を装着した 一層ラーメンの水平力と水平変位の関係式および等価粘 性減衰定数を理論的に解明する. また，上述の摩擦力を 生成する原理と静的力学特性に関する関係式を模型実験 によって検証した結果について述べる. 最後に, 提案の 減衰装置の振動減衰装置としての可能性を述べる.

\section{2. 摺動型減衰装置の基本構造と静的力学モデル}

\section{（1）凹型・凸型摺動体の基本構造}

提案の減哀装置を構成する凹型摺動体と凸型摺動体の 基本形状を図一1 に示寸. 几型摺動体と凸型摺動体はそ れぞれ二つの $x$ 軸方向昇り勾配 $i$ の前方用摺動面と, 一 つの $x$ 軸方向下り勾配 $i$ の後方用摺動面を持つ. 後方用 摺動面は左右の前方用摺動面の間に配置する. ここで, 図では摺動面の下り方向を矢印の向きで示し，勾配の大 きさを正の実数 $i$ で示す. $l_{d}$ は二つの摺動体の水平長 さであり， $b_{F}$ と $b_{B}$ はそれぞれ前方用摺動面と後方用 摺動面の幅である. $x$ 軸方向が減衰装置の作動方向であ る. 凹型摺動体と凸型摺動体は，互いの前方用摺動面同 土および後方用摺動面同士が対面かつ接触するように組 み立てられる。

組み立てられた凹型・凸型摺動体とその摺動変形を図 -2 に示寸．図(a)は，前方移動時の凹型・凸型摺動体の 摺動変形と, 作動方向に平行な凹型摺動体と凸型摺動体 の正の相対変位すなわち摺動変位 $u_{d}$ を表わす. 前方移 動時には二つの摺動体の前方用摺動面同士が接触し，後 方用摺動面は接触しない．図(b)は後方移動時の摺動変 形と負の摺動変位を表わす。後方移動時には後方用摺動 面同士が接触し，前方用摺動面は接触しない，中立時は， 摺動変位が $u_{d}=0$ であり, 前方用摺動面と後方用摺動 面が共に接触する状態と定義する．中立時の凹型・凸型 摺動体の高さを $h_{d}$ とする. 二つの前方用摺動面の中間 に後方用摺動面を配置しているので，摺動時の凹型・凸 型摺動体は，前方移動時と後方移動時に拘わらず，作動 方向に直角な横断方向（図-1の $z$ 軸方向）の偏心が発 生しない.

凹型・凸型摺動体に摺動変位 $u_{d}$ が生じると, 凹型・ 凸型摺動体の高さは $h_{d}$ から $h_{d}+v_{d}$ に変化する. ここに, 


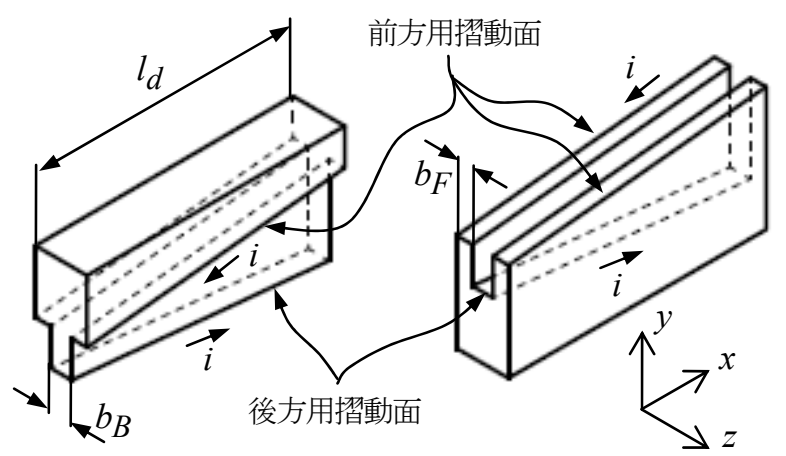

(a) 凸型摺動体

(b) 凹型摺動体

図-1兄型摺動体と凸型摺動体の基本形状

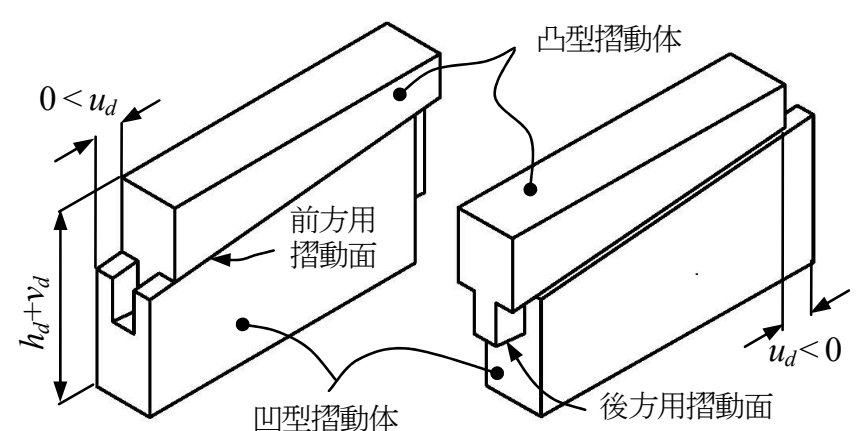

(a) 前方移動時

(b) 後方移動時

図一2 組み立てられた凹型・凸型摺動体と摺動変形

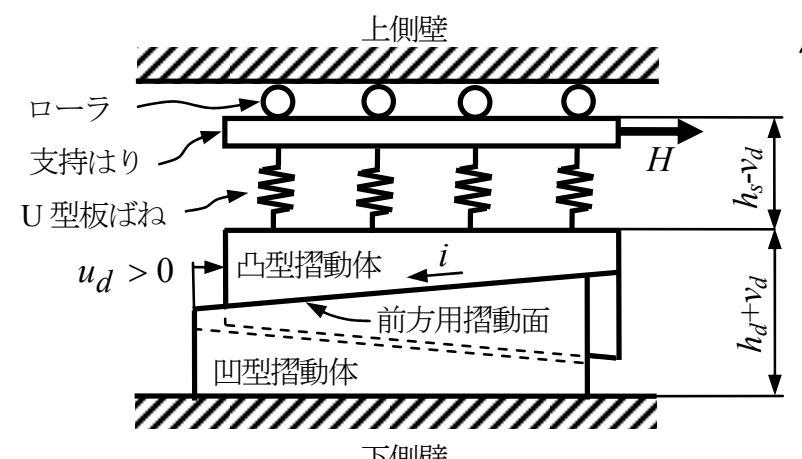

下側壁

(a) 前方移動時 $\left(u_{d}>0\right)$
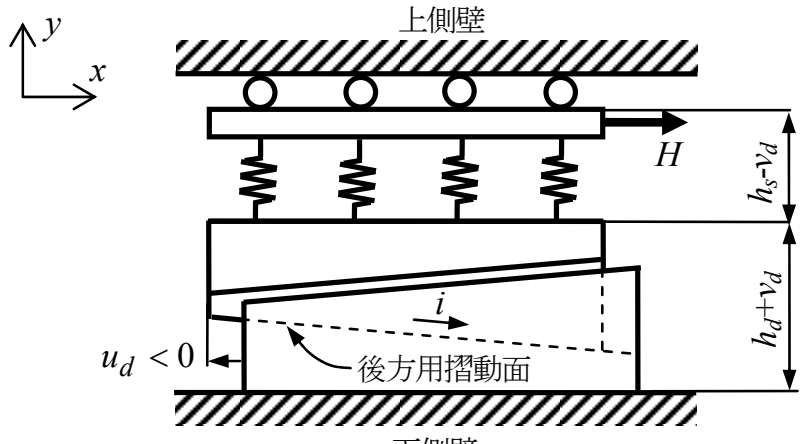

下側壁

(b) 後方移動時 $\left(u_{d}<0\right)$

図一3 ローラで支持された摺動型減衰装置の力学モデル

$v_{d}$ は凹型・凸型摺動体の高さの変化であり，次式で表 される。

$$
v_{d}=i\left|u_{d}\right|
$$

高さの変化 $v_{d}$ は摺動変位 $u_{d}$ の絶対值に比例するので, この特性を利用して摺動面に摺動変位の絶対值に比例し て増加する圧縮力を発生させることを考える.

\section{（2）摺動型減衰装置の静的力学モデル}

図－3 は，凹型摺動体，凸型摺動体，U 型板ばねおよ び支持はりで構成する摺動型減衰装置をローラで支持し た力学モデルである. 図に示すように，凹型摺動体を下 側壁に固定し，凸型摺動体の上側に $U$ 型板ばねと支持 はりを設置する．支持はりと上側壁の間にローラを設置 し，支持はりを水平方向（x 軸方向）に可動となり，鉛 直方向（ $y$ 軸方向）に固定となるようにローラで支持す る。ローラは減衰装置の力学特性を説明するために用い るが，減衰装置の構成に必須の条件ではない，上側壁と 下側壁の鉛直方向の間隔は一定であり，これらは上下左 右に動かない，なお，減衰装置の弾性変形としては，U 型板ばねの弾性変形のみを考慮し，凹型摺動体と凸型摺 動体および支持はりの弾性変形は無視する．また，中立
時の支持はりとU 型板ばねの合計高さを $h_{s}$ とする.

図(a)は，支持はりに水平力 $H$ が作用し，凹型・凸型 摺動体に正の摺動変位 $\left(u_{d}>0\right)$ が生じ, 前方用摺動面 のみが接触する前方移動時を示す。困(b)は，支持はり に水平力 $H$ が作用し, 負の摺動変位 $\left(u_{d}<0\right)$ が生じ, 後方用摺動面のみが接触する後方移動時を示す. 前方移 動時と後方移動時に拘わらず，摺動変位 $u_{d}$ が生じると， 凹型・凸型摺動体の高さは $v_{d}$ だけ増加し，U 型板ばね と支持はりの合計高さは $v_{d}$ だけ減少する. 高さの変化 $v_{d}$ は $\mathrm{U}$ 型板ばねの縮みに等しく，高さの変化 $v_{d}$ と摺 動変位 $u_{d}$ の関係は式(1)で示されるので, 凹型・凸型摺 動体には摺動変位の絶対值に比例して増加する圧縮力が 作用する.

支持はりに水平力 $H$ が作用すると， $U$ 型板ばねは水 平方向にも変形する．減衰装置としての機能を考えると， 凹型・凸型摺動体の摺動変位で成される仕事と水平力 $H$ が成す仕事の差が小さくなるほど効率が良いので，U 型 板ば水の水平方向の弾性変形は作動方向の口型・凸型摺 動体の摺動変形に比べて小さいほうが望ましい. なお, U 型板ばねの詳細は後述する.

図－4 は，図一3(a)に示した前方移動時 $\left(u_{d}>0\right)$ にお いて, 凹型・凸型摺動体の摺動速度 $\dot{u}_{d}$ が正となる前進 

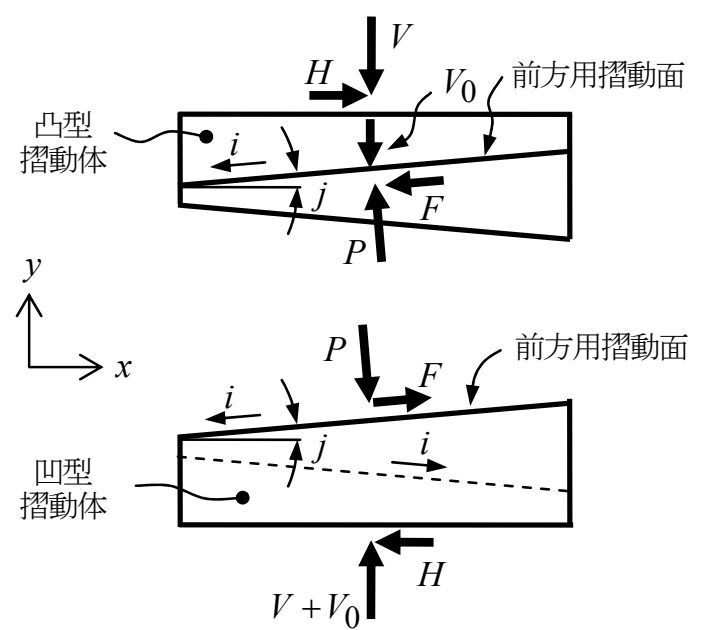

図-4 前方移動・前進時の凹型摺動体と凸型摺動 体の自由物体図 $\left(u_{d}>0, \dot{u}_{d}>0\right)$

時 $\left(\dot{u}_{d}>0\right)$ の凹型摺動体と凸型摺動体の自由物体図で ある.ここに， $V$ はばねによる圧縮力， $V_{0}$ は凸型摺動 体と $\mathrm{U}$ 型板ばねおよび支持はりの自重などの初期圧縮 力, $H$ は図一3(a)に示寸支持はりに作用寸る水平力, $P$ は摺動面に垂直に作用する垂直抗力， $F$ は摺動面に平行 に作用するクーロン摩擦力とする．初期圧縮力としてば ねの圧縮力も利用できる. $j$ は摺動面が $x$ 軸とな寸角度 とし， $i=\tan j$ が成り立つ. なお， ローラの摩擦は無視 する.

前方用摺動面の動摩擦係数を $\mu_{F}$ と寸ると, 摩擦力 $F$ と垂直抗力 $P$ の関係は次式で表わされる.

$$
F=\mu_{F} P
$$

減衰装置の鉛直ばね定数（ $y$ 軸方向）を $S_{y}$ とすると, 圧縮力 $V$ は次式で表わされる。

$$
V=S_{y} v_{d}
$$

式(3a)に式(1)の関係を用いると次式を得る.

$$
V=S_{y} i\left|u_{d}\right|
$$

図－4の凸型摺動体の水平方向と鉛直方向の力のつり 合い式はそれぞれ次式となる。

$$
\left.\begin{array}{c}
H-F \cos j-P \sin j=0 \\
-V-V_{0}-F \sin j+P \cos j=0
\end{array}\right\}
$$

式(2)，式(3b)および式(4)より，垂直抗力 $P$, 摩擦力 $F$ お よび圧縮力 $V$ を消去すると, 次の水平力 $H$ と摺動変位 $u_{d}$ の関係式を得る.

$$
H=\lambda\left(S_{y} i\left|u_{d}\right|+V_{0}\right)
$$

ここに， $\lambda$ は前方用摺動面の動摩擦係数と勾配によっ て決まる次式の運動抵抗係数である.

$$
\lambda=\left(\mu_{F}+i\right)\left(1-\mu_{F} i\right)^{-1}, \quad u_{d}>0, \dot{u}_{d}>0
$$

同様にして, 前方移動・後進時 $\left(u_{d}>0, \dot{u}_{d}<0\right)$, 後 方移動・後進時 $\left(u_{d}<0, \dot{u}_{d}<0\right)$ および後方移動・前進 時 $\left(u_{d}<0, \dot{u}_{d}>0\right)$ のそれぞれの水平力と摺動変位の関 係も式(5)で示される.ただし，運動抵抗係数は下式と する.

$$
\lambda=\left\{\begin{array}{c}
-\left(\mu_{F}-i\right)\left(1+i \mu_{F}\right)^{-1}, u_{d}>0, \dot{u}_{d}<0 \\
\left(\mu_{B}-i\right)\left(1+i \mu_{B}\right)^{-1}, u_{d}<0, \dot{u}_{d}>0 \\
-\left(\mu_{B}+i\right)\left(1-i \mu_{B}\right)^{-1}, u_{d}<0, \dot{u}_{d}<0
\end{array}\right.
$$

ここに， $\mu_{B}$ は後方用摺動面の動摩擦係数である.また， 水平力 $H$ が作用しない状態で，圧縮力 $V$ と初期圧縮力 $V_{0}$ の作用でロ型・凸型摺動体が中立状態に戻らないよ うに, 動摩擦係数と摺動面の勾配には $\mu_{F}>i$ および $\mu_{B}>i$ の関係を仮定する.

摺動面の動摩擦係数は面圧，摺動速度および摺動振幅 などによって変化すると考えられるが，適切な材料を組 み合わせることにより動摩擦係数の変化を小さくするこ とも可能である ${ }^{9}$. よって，本論文では，動摩擦係数は 摺動面の面圧, 摺動速度および摺動振幅によって変化し ないと仮定する。 また, 摺動面が固着を脱し, 減衰装置 が作動を開始する状態は, 静止摩擦力を考慮した動力学 的な手法により説明する必要がある．本論文では，静力 学的な手法により作動中の減衰装置の力学特性を説明し, 静止摩擦力の影響の解明は今後の課題とする.

凹型・凸型摺動体の摺動振幅を $a_{d}$ とすると，減衰装 置の $\mathrm{U}$ 型板ばねに縮み $a_{d}$ を発生させる力は $S_{y} a_{d}$ とな る. 式(5)の両辺を $S_{y} a_{d}$ で割ると次式を得る.

$$
\frac{H}{S_{y} a_{d}}=\lambda\left(\frac{V_{0}}{S_{y} a_{d}}+\frac{i\left|u_{d}\right|}{a_{d}}\right)
$$

図－5 は式(7)で計算した水平力と摺動変位の履歴曲線 の一例である．横軸と縦軸はそれぞれ無次元化した摺動 変位 $u_{d} / a_{d}$ と無次元化した水平力 $H / S_{y} a_{d}$ を表わす. 図(a)は摺動面の勾配が $i=0.01$ と $i=0.04$ の場合の履歴 曲線の比較であり, 無次元化された初期圧縮力は $V_{0} / S_{y} a_{d}=0.01$ であり, 摺動面の動摩擦係数は 0.2 で ある. 図(b)は初期圧縮力が $V_{0} / S_{y} a_{d}=0.005$ と 0.020 の場合の履歴曲線の比較であり, 摺動面の動摩擦係数と 勾配はそれぞれ 0.2 と 0.02 である. 何れの条件の履歴曲 線も蝶が羽を広げた形になると予想される.

図(a)より，摺動面の勾配を大きくすると，前方移動， 後方移動，前進および後進のそれぞれに拘わらずに履歴 曲線の傾きが増加し，曲線が囲む面積が大きくなると考 えられる. 図(b)より，初期圧縮力を大きくすると，曲 線の傾きは変化しないが，縦軸の切片の值が大きくな 


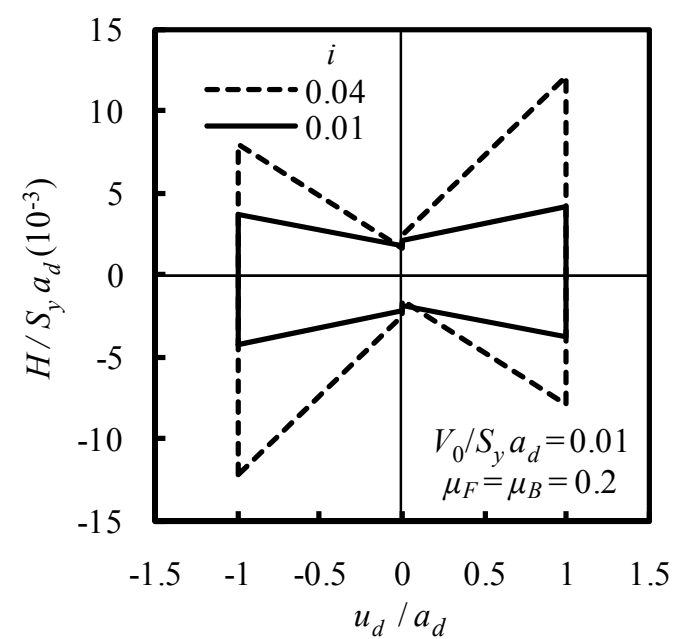

(a) 摺動面の勾配による比較

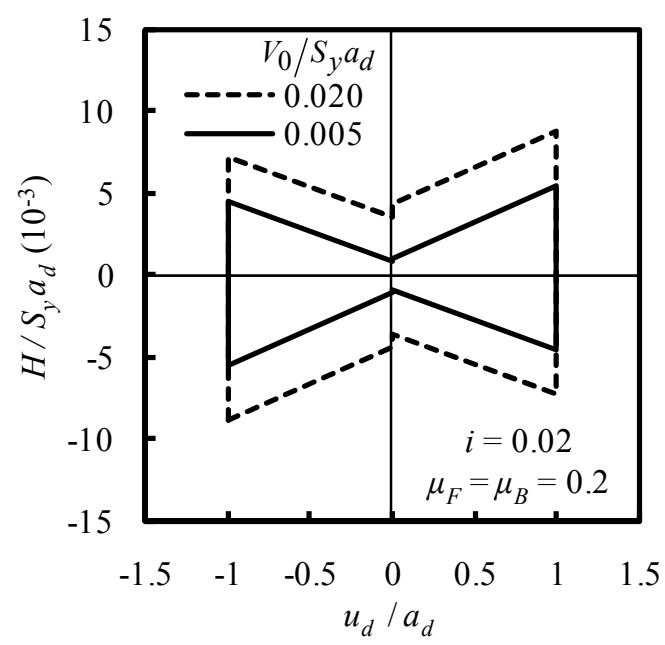

(b) 初期圧縮力による比較

図－5 ローラで支持された摺動型減衰装置の水平力と摺動変位の履歴曲線

り，曲線が上下に膨らむことにより，全体として曲線が 囲む面積が大きくなると考えられる．また，図一5 の縦 軸は鉛直ばね定数 $S_{y}$ で無次元化されているので，鉛直 ばね定数 $S_{y}$ のみを大きくすると, 履歴曲線が囲む面積 が大きくなると考えられる．動摩擦係数のみを大きく すると図(a)と図(b)の特徵が同時に現れて，履歴曲線が 囲む面積が大きくなると考えられる，履歴曲線が囲む面 積が摩擦力によって消費される力学エネルギーを示すの で，摺動面の動摩擦係数，摺動面の勾配，鉛直ばね定数 および初期圧縮力を適宜組み合わせることにより，所要 のエネルギー吸収能力を持つ振動減衰装置を実現できる と考えられる.

また，図一5(b)に示すように，初期圧縮力を小さくす ることにより, 縦軸の切片の值すなわち中立時の摩擦力 を小さくし，摺動面が固着を脱し減衰装置が作動を開始 する作動力の限界を小さくできると考えられる．例えば， 凸型摺動体，板ばねおよび支持はりを構造物に吊り下げ ることにより自重による初期圧縮力を小さくできると考 えられる. 初期圧縮力を小さくすると, 履歴曲線が囲む 面積は小さくなるが，図一5(a)に示すように，摺動面の 勾配または減衰装置の鉛直ばね定数を大きくすることに より，面積の減少を補えると考えられる.

式(7)において初期圧縮力をゼロとし，式(6a)と式(6b) において摺動面の勾配 $i$ を無視すると, 提案の摺動型減 衰装置が描く履歴曲線は Clough and Penzien が示した履 歴減衰の曲線 ${ }^{12}$ おおよび若林らの減衰装置が描く履歴曲 線 ${ }^{14)}$ と同等となると考えられる.

また，図一5 と類似の履歴曲線を持つエネルギ一吸収 装置として輪ばねが実用化されている。輪ばねは，内側 に円すい面を有する外輪と外側に円すい面を有する内輪 を, 円すい面で瓦いに接触するよう組み立てて積み上げ たものである。輪ばねの個数を増減させることにより
摩擦力の大きさを調整できる. 大きな摩擦力を得ること ができるため，機械部品の緩衝装置などに用いられてい る ${ }^{15}$. 輪ばねを用いた構造物の振動を抑制する減衰装 置が考案されているが ${ }^{16}$, 筆者らの文献調查の範囲内 では，その減衰装置の具体的な力学特性や実構造物への 適用に関する報告等は確認できなかった。

\section{（3）摺動型減哀装置の等価粘性減哀係数}

図－3 の力学モデルにおいて，1 サイクルで消費され る力学エネルギーは, 図一5 で示した履歴曲線が囲む面 積に等しい，実用的には動摩擦係数は 0.3 未満，摺動面 の勾配は数\%程度と考えられるので，式(6a) と式(6b)の 分母は $1 \pm \mu_{F} i \approx 1$ および $1 \pm \mu_{B} i \approx 1$ と考えて良い. 前方 用摺動面と後方用摺動面の動摩擦係数を $\mu_{F}=\mu_{B}=\bar{\mu}$ とし，ローラで支持された減衰装置の 1 サイクルの散逸 エネルギーを $\Delta_{f r i}$ とすると，この散逸エネルギーは次 式で表わされる.

$$
\Delta_{f r i} \approx \bar{\mu} a_{d}\left(2 i S_{y} a_{d}+4 V_{0}\right)
$$

式(8)より，減衰装置が散逸するエネルギーは摺動振幅 の二次関数となるが，振動数とは無関係であると考えら れる. 一方, 粘性減衰係数 $c_{e}$ の減衰装置が円振動数 $\theta$ と振幅 $a_{d}$ で振動する時の 1 サイクルの散冕エネルギー を $\Delta_{v i s}$ とすると，この散逸エネルギーは次式で表わさ れる.

$$
\Delta_{v i s}=\pi c_{e} \theta a_{d}^{2}
$$

式(8)と式(9)の互いの右辺を等值すると, 次の等価粘性 減衰係数 $c_{e}$ を得る.

$$
c_{e}=\frac{\bar{\mu}}{\pi \theta}\left(2 i S_{y}+\frac{4 V_{0}}{a_{d}}\right)
$$


式(10)は分母に円振動数 $\theta$ を変数として含むので, $\theta$ が小さくなるとすなわち周期が長くなると等価粘性減衰 係数は増加する. これは提案の減衰装置に限らず摩擦型 減衰装置に共通の特徴である。これより, 摩擦型減衰装 置と同様に, 提案の減衰装置は長周期の構造物に適して いると考えられる.

式(10)の右辺第 2 項の $4 V_{0} / a_{d}$ は分母に摺動振幅 $a_{d}$ を変数として含むので, 摺動振幅が大きくなると, この 項の等価粘性減衰係数への寄与は減少寸る. これは振幅 が大きくなると等価粘性減衰係数が減少する摩擦力一定 の摩擦型減衰装置と共通の特徵と考えられる. しかし, 大振幅の振動を対象とする減衰装置では, 振幅の増加に 対して等価粘性減衰係数が減少しないことが望ましい. また，この項は分子に初期圧縮力 $V_{0}$ を変数として含む ので，初期圧縮力を大きくするとこの項の等価粘性減衰 係数への寄与は大きくなるが, 中立時の静止摩擦力も大 きくなるので, 減衰装置が作動を開始する作動力の限界 が大きくなる．前項で述べたように，提案の減衰装置で は初期圧縮力を小さくすることにより，減衰装置が作動 を開始する作動力の限界を小さくできると考えられる.

式(10)の右辺第 1 項の $2 i S_{y}$ は摺動振幅 $a_{d}$ を変数とし て含まないので, 摺動振幅が無限大に大きくなると, 式 (10)の $c_{e}$ は一定值 $c_{e 0}=2 \bar{\mu} i S_{y} / \pi \theta$ に漸近する. よって, 提案の減衰装置は, 振幅の大小に拘わらずに, 最低でも $c_{e 0}$ で示される等価粘性減衰係数を確保できると考え られる.つまり, 初期圧縮力を小さくして等価粘性減衰 係数の振幅依存性を小さくしながら, 動摩擦係数, 勾配 および鉛直ばね定数を適宜組み合わせることにより，必 要減衰性能を $c_{e 0}$ として確保できると考えられる.こ れは, 摩擦力が変位の絶対值に比例して増加する提案の 減衰装置に特有の特徵であると考えられる.

以上より，摺動面の動摩擦係数，摺動面の勾配，鉛直 ばね定数および初期圧縮力を適宜組み合わせることによ り，提案の減衰装置は，長周期の構造物に対して，小振
幅から大振幅まで所定の等価粘性減衰係数で示される減 衰性能を確保できると考えられる.

\section{(4) U 型板ばね}

図一6に U 型板ばねの基本形状を示すはばねは，鉛 直方向（ $y$ 軸方向）の復元力を発生する U 形状の板ばね 部と, ばねを対象物に固定するための平板状の上下の固 定部で構成する. 固定部には固定用のボルト孔を設置す る. ここに，記号 $\alpha, \beta, \gamma, \phi, E, G$ はそれぞれ直線 部長さ, 曲げ半径, 長さ, 板厚, ヤング率およびせん断 弾性係数である. 減衰装置の作動方向は $x$ 軸方向である.

図ー7 は U 型板ばねの力学モデルであり, 圧縮力 $p$ が作用して鉛直変位 $v_{S}$ を生じた状態を示す，図に示す ように U 型板ばねを両端の曲げ変形が拘束された U 型 の曲がり梁と考えると，曲げ変形のみを考慮した鋁直ば ね定数 $s_{y}$ は次式で見積もられる ${ }^{17)}$.

$$
\begin{gathered}
s_{y}=\frac{\sigma \gamma E}{2} \times\left(\frac{\phi}{\beta}\right)^{3} \\
\sigma=\frac{1}{4 \xi^{3}+3 \pi-\frac{6\left(2-\xi^{2}\right)^{2}}{2 \xi+\pi}}
\end{gathered}
$$

ここに, 式(11b)の $\sigma$ は, 直線部の長さと半径の比 $\xi=$ $\alpha / \beta$ を変数とする係数である. 式(11a) と式(11b)より, 板厚と半径の比, 直線部の長さと半径の比, および材料 を適切に選ぶことにより, 所要の鉛直ばね定数を持つ $\mathrm{U}$ 型板ばねが得られると考えられる.

一方，U 型板ばねを二辺が固定された幅 $\times$ 高 $\times$ 厚 $=$ $\gamma \times(2 \alpha+\pi \beta) \times \phi$ の矩形板と見なし，水平方向（図一6 の $x$ 軸方向）の変形を両端固定梁の曲げ変形と矩形板の せん断変形の和として近似すると， $x$ 軸方向の水平ばね 定数 $s_{x}$ は次式で表わされる.

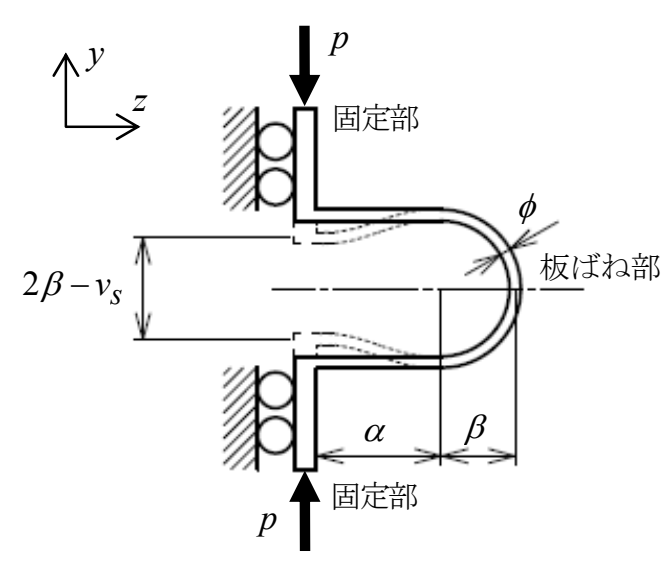

図-7 U 型板ばねの力学モデル 


$$
s_{x} \approx \frac{\gamma E}{2 \xi+\pi} \times \frac{\left(\frac{\phi}{\beta}\right)}{\frac{\tau E}{G}+(2 \xi+\pi)^{2}\left(\frac{\beta}{\gamma}\right)^{2}}
$$

ここに， $\tau$ はせん断応力度の分布を表わす係数である. $\xi=1, \tau=3 / 2, G / E \simeq 0.385$ (ポアソン比 0.3 の等方 性材料と仮定する）の条件で，式(12)の水平ば水定数と 式(11a)の鉛直ばね定数の比を試算すると次式を得る.

$$
\frac{s_{x}}{s_{y}} \approx \frac{4.77}{\left(\frac{\phi}{\beta}\right)^{2}\left\{3.90+26.4\left(\frac{\beta}{\gamma}\right)^{2}\right\}}
$$

ここで，ばねの板厚と半径の比を $\phi / \beta=1 / 20$, 半径と 長さの比を $\beta / \gamma=1 / 10$ とすると, ばね定数比は $s_{x} / s_{y}$ $\approx 458$ となる. よって, $\phi / \beta$ と $\beta / \gamma$ を適切に設定する ことにより， $s_{x} \gg s_{y}$ となる U 型板ばねを作ることがで きると考えられる.

$\mathrm{U}$ 型板ばねの固定部の一方を凸型替動体にボルトなど で固定し，反対側の固定部を支持はりにボルトなどで固 定する，ばねの個数を $n$ とすると，減衰装置の鉛直ばね 定数 $S_{y}$ は次式で表される.

$$
S_{y}=\psi n s_{y}
$$

ここに， $\psi$ はばねの取り付け方法や各ばねに作用する 力のばらつきなどを考慮する補正係数とし，実験により 定める. 減衰装置の水平ば水定数も同様にして決定でき るが，ここでは記述を省略する.

\section{3. 摺動型減衰装置を装着した一層ラーメンの静 的力学特性}

\section{(1) 摺動型減衰装置の配置}

図一3 に示したように, 提案の減衰装置に水平力が作 用すると，減衰装置では口型摺動体と凸型摺動体が水平 方向にずれる摺動変位が生じる. この摺動変位は水平 力が作用するラーメンで生じる上下間の層間水平変位と 類似していると考えられる. 摺動変位の方向と層間水平 変位の方向が平行になるように減衰装置をラーメンに装 着することにより，ラーメンの減衰を増加させることが できると考えられる，ここでは，提案の減衰装置の実用 性を検討するために, 減衰装置を装着した一層ラーメン の水平力と水平変位の関係式および等価粘性減衰定数を 理論的に明らかにする. 水平力と水平変位の関係式の妥 当性は次章で述べる模型実験で具体的に検証される.

図－8 は，一層ラーメンにおける減衰装置の配置を説 明する力学モデルである. 上側壁を梁の下側に柱と衝突 しない適切な間隔 $e$ を設けて設置し，下側壁を基礎の上 側に柱と衝突しない適切な間隔 $e$ を設けて設置する. 減 衰装置は下側壁と上側壁の間に設置し，支持はりは上側 壁に固定し，凹型摺動体は下側壁に固定する。U 型板ば ねは凸型摺動体と支持はりを挟むようにそれらの側面に 固定する. ここに， $l$ と $l_{d}$ はそれぞれ梁および上側壁と 下側壁の長さとし， $h, h_{u}$ および $h_{l}$ は柱の高さ，上側 壁の高さおよび下側壁の高さとする。 $A_{b} ， I_{b}$ および $E_{b}$ はそれぞれ梁の断面積, 断面二次モーメントおよび ヤング率とし， $A_{c} ， I_{c}$ および $E_{c}$ はそれぞれ柱の断面 積, 断面二次モーメントおよび ヤング率とする。また, ラーメンの梁の曲げ岡性は柱のそれに比べて大きく，す

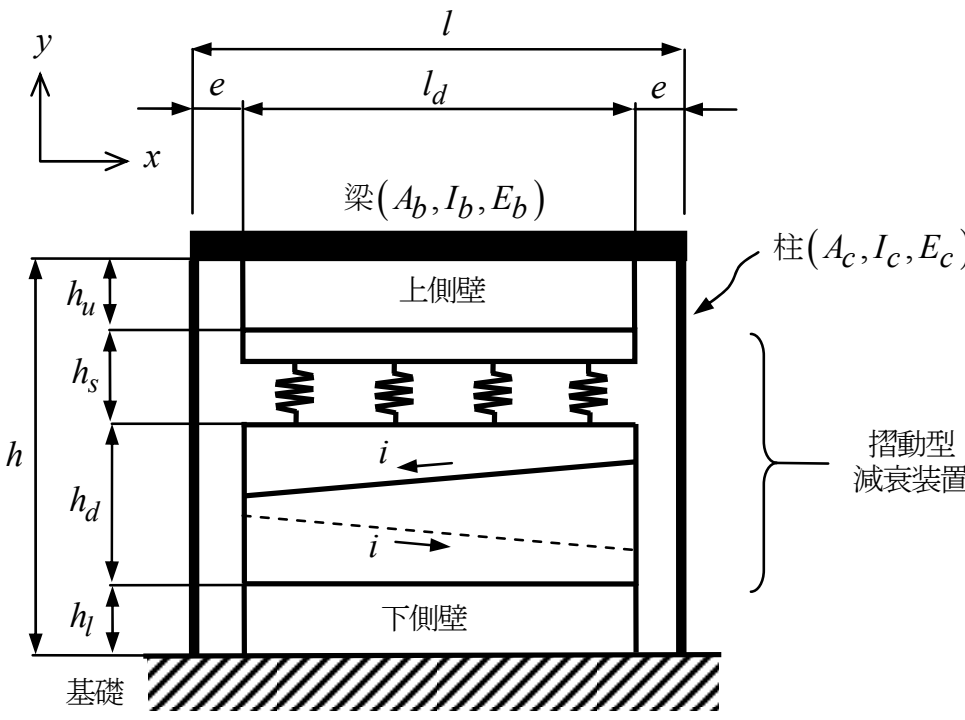

(a) 正面図

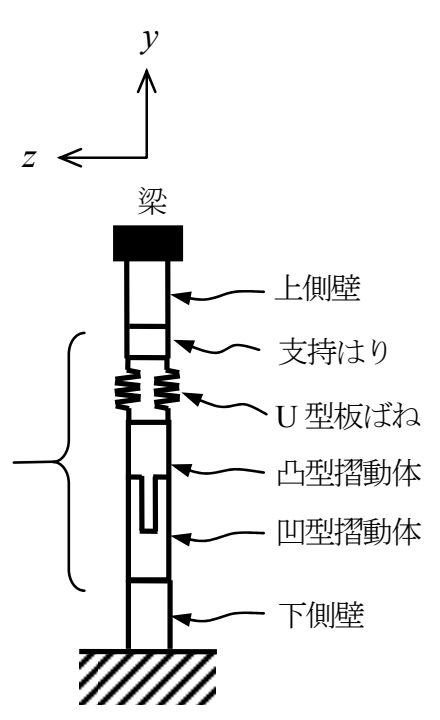

(b) 中央断面図

図－8 一層ラーメンにおける摺動型減衰装置の配置と力学モデル 
なわち, $E_{b} I_{b} / l \gg E_{c} I_{c} / h$ が成り立ち, 梁の曲げ変形 を無視する．上敗壁と下側壁のそれぞれの水平方向 $(x$ 軸方向）と鉛直方向（ $y$ 軸方向）の剛性は，減衰装置の 鉛直ばね定数と水平ばね定数に比べて十分に大きいと仮 定し，上側壁と下側壁の変形は無視する．よって，梁の 水平変位と凹型・凸型摺動体の摺動変位の差は無視でき る程度に小さいと仮定し， $u \approx u_{d}$ とする.

\section{（2）ラーメン水平変位の履歴曲線}

図一9 はラーメンの梁に水平力 $Q$ が作用した時のラー メンと提案の減衰装置の変形を説明する図である。図 (a)は前方移動時の代表的な変形である. ラーメンの柱 には曲げ変形と軸変形が生じ, 柱の上端に水平変位 $u$ と 鉛直変位 $v$ を生じる，几型・凸型摺動体は，正の摺動変 位 $u_{d}$ を生じ，前方用摺動面で接触し，高さ変化 $v_{d}$ を生 じる．図(b)は後方移動時の代表的な変形である．前方 移動と同様に，柱には曲げ変形と軸変形が生じ，柱の上 端に水平変位と鉛直変位を生じる．回型・凸型摺動体は, 負の摺動変位 $u_{d}$ が生じ, 後方用摺動面で接触し, 高さ 変化 $v_{d}$ を生じる. 前方移動時と後方移動時共に, $v_{d}$ と $u_{d}$ には式(1)の関係が成立する. 凹型・凸型摺動体の高 さの変化と柱の高さの変化の差 $\left(v_{d}-v\right)$ は, $\mathrm{U}$ 型板ばね の弾性変形で吸収される．U型板ばねの弾性変形に比例 して減衰装置に圧縮力が生じ，その圧縮力によりラーメ ンの梁の水平移動に抵抗する摩擦力が減衰装置に発生す ると考えられる.

図ー10は, 図一9(a)の前方移動時の状態で, ラーメ ンと減衰装置を切り離して，上側壁と支持はりに作用寸 る水平力 $\bar{H}$ と鉛直力 $\bar{V}$ を明示した自由物体図である. 提案の減衰装置は四型・凸型摺動体の高さの変化を利用 して圧縮力を生成するので，柱の高さの変化は減衰装置 が生成する圧縮力に大きく影響すると考えられる. よっ
て, 柱の曲げ変形に起因する二次鉛直変位を考慮して, 柱上端の鉛直変位 $v$ は下式で表わす。

$$
v=v_{1}+v_{2}
$$

ここに， $v_{1}$ は柱の軸変形による一次鉛直変位であり， $v_{2}$ は柱の曲げ変形による二次鉛直変位とする. 柱の軸 変形に着目したラーメンの鉛直ばね定数を $K_{y}$ とすると， 一次鉛直変位は次式で表わされる.

$$
v_{1}=\frac{\bar{V}}{K_{y}}
$$

柱の本数は左右の二本なので, 鉛直ばね定数 $K_{y}$ は次式 で表わされる。

$$
K_{y}=\frac{2 A_{c} E_{c}}{h}
$$

柱の曲げ変形を支点変位 $u$ が生じる両端固定梁の曲げ 変形と等価と仮定し，柱の二次鉛直変位を両端固定梁の 元の長さと両端固定梁のたわみ曲線の曲線長の差と考え て，二次鉛直変位を次式で表わ寸。

$$
v_{2}=-\frac{3}{5 h} u^{2}
$$

式(18)は支点変位が生じる両端固定梁のたわみ曲線を積 分することにより簡単に求められるので，ここでは式 (18)の誘導の過程は省略する.

$\mathrm{U}$ 型板ばねの縮みは $\left(v_{d}-v\right)$ なので, 減衰装置に作用 する鉛直力は次式で表わされる.

$$
\bar{V}=S_{y}\left(v_{d}-v\right)
$$

式(19)に式(1), 式(15), 式(16), 式(18)および $u_{d} \approx u$ を 適用すると次式を得る.

$$
\bar{V}=\bar{S}_{y}\left(i|u|+\frac{3}{5 h} u^{2}\right)
$$

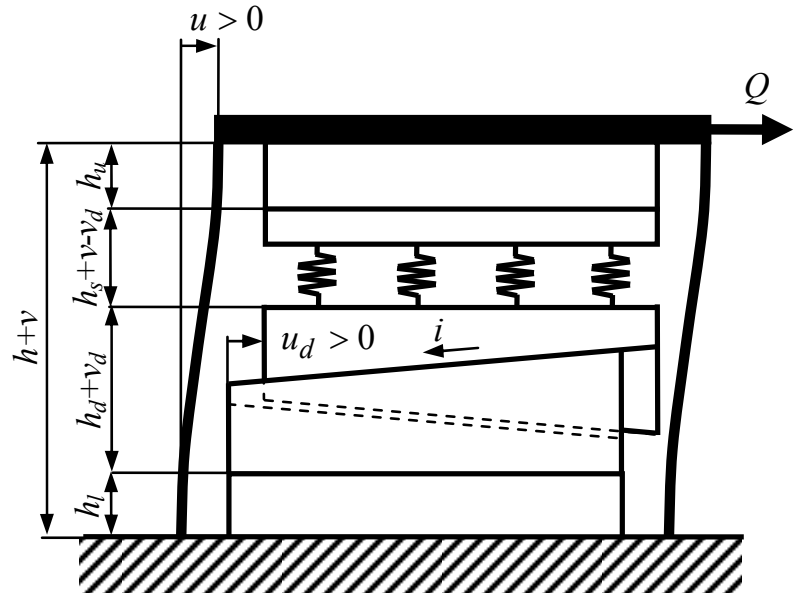

(a) 前方移動時 $\left(u>0, u_{d}>0\right)$

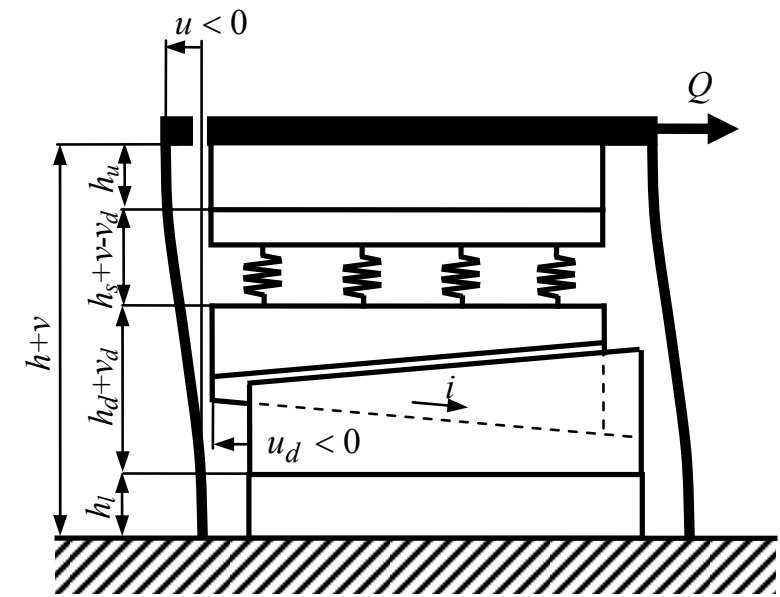

(b) 後方移動時 $\left(u<0, u_{d}<0\right)$

図-9 ラーメンと摺動型減衰装置の変形 


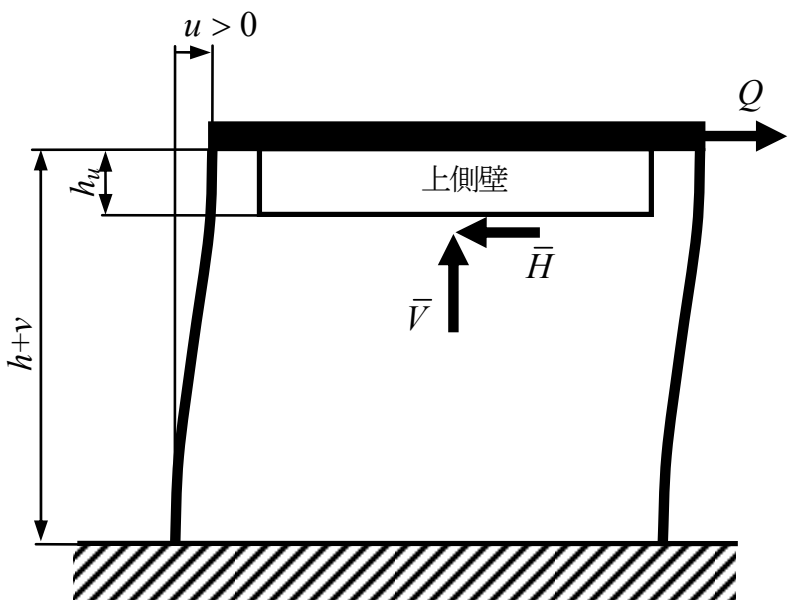

(a) ラーメンに作用する力

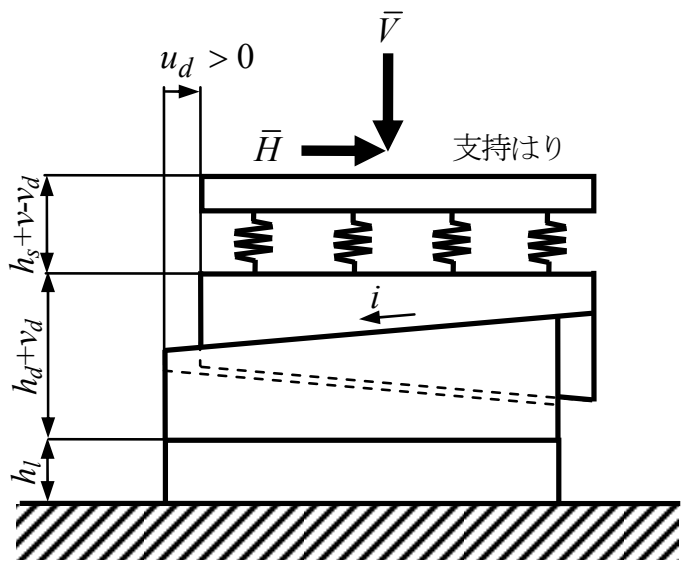

(b) 摺動型減衰装置に作用する力

図-10 前方移動時 $\left(u>0, u_{d}>0\right)$ のラーメンと摺動型減衰装置の接続部に作用する力

$$
\bar{S}_{y}=\frac{S_{y}}{1+S_{y} / K_{y}}
$$

ここに， $\bar{S}_{y}$ はラーメンと減衰装置の合成鉛直ばね定数 である. 式(20a)で表わされる鉛直力 $\bar{V}$ と図-10 の水平 力 $\bar{H}$ を，式(4)の $V$ と $H$ に置き換えると，水平力 $\bar{H}$ は 次式で表わされる.

$$
\bar{H}=\lambda\left\{\bar{S}_{y}\left(i|u|+\frac{3}{5 h} u^{2}\right)+V_{0}\right\}
$$

梁の水平変位に着目したラーメンの水平ばね定数を $K_{x}$ とすると, 水平力 $Q, \bar{H}$ および水平変位 $u$ の関係は 次式で表わされる.

$$
Q-\bar{H}=K_{x} u
$$

柱の変形は支点変位を生じる両端固定梁の変形と等価と 考えているので，ラーメンの水平ばね定数は次式で表わ される。

$$
K_{x}=\frac{24 E_{c} I_{c}}{h^{3}}
$$

式(22)に式(21)を代入し整理すると，次の減衰装置を装 着したラーメンの水平力 $Q$ と水平変位 $u$ の関係式を得 る.

$$
\frac{Q}{h \bar{S}_{y}}=\frac{K_{x}}{\bar{S}_{y}}\left(\frac{u}{h}\right)+\lambda\left\{\frac{V_{0}}{h \bar{S}_{y}}+i\left|\frac{u}{h}\right|+\frac{3}{5}\left(\frac{u}{h}\right)^{2}\right\}
$$

図ー11 は式(24)で計算した減衰装置を装着したラーメ ンの水平力と水平変位の履歴曲線である. 図(a)と図(b) はそれぞれ初期圧縮力と摺動面の公配による履歴曲線の 変化を示す. 図(a)より, 初期圧縮力のみを大きくする と, 前進時または後進時の曲線の傾きは変わらないが, 縦軸の切片が大きくなることにより曲線が上下に膨らみ,
全体として曲線が囲む面積が大きくなると考えられる. 図(b)より，摺動面の勾配のみを大きくすると，縦軸の 切片は変わらないが, 前方移動・前進時と後方移動・後 進時の曲線の傾きが大きくなり, 前方移動・後進時と後 方移動・前進時の曲線の傾きが小さくなることにより， 全体として曲線が囲む面積が大きくなると考えられる. また，これらの図より，いずれの履歴曲線の形状も蝶が 羽を広げた時の羽の形状に似ると予想される.

式(24)の左辺は，ラーメンと減衰装置の合成鉛直ばね 定数 $\bar{S}_{y}$ を含んでいる. ラーメンの鉛直ばね定数と減衰 装置の鈶直ばね定数の関係を $K_{y} \gg S_{y}$ と仮定すると, $\bar{S}_{y} \approx S_{y}$ と見なせる. この仮定の下で $S_{y}$ のみを大きく すると, 式(24)の左辺の水平力 $Q$ は大きくなるので, 履 歴曲線が囲む面積は大きくなる. よって, 摺動面の動摩 擦係数，摺動面の勾配，初期圧縮力および鈆直ばね定数 を大きくすることにより，ラーメンの水平力と水平変位 の履歴曲線が囲む面積を大きくすることができると考え られる。

以上より，これらの4つのパラメータを適宜組み合わ せることにより，提案の減衰装置はラーメンに所定の減 衰を付加できると考えられる．ただし，式(6a)と式(6b) の運動抵抗係数が正負の值となることから，減衰装置を 装着したラーメンの水平力と水平変位の履歴曲線の勾配 が負とならないように，4 つのパラメータを決定する必 要があると考えられる. 例えば，式(24)の初期圧縮力と 二次鉛直変位を無視できる場合は， $K_{x}+i \lambda \bar{S}_{y}>0$ が常 に成立するように摺動面の動摩擦係数, 摺動面の公配お よび鉛直ばね定数を決定する必要があると考えられる.

\section{(3) 等価粘性減衰定数}

ラーメンの二次鉛直変位を無視すると, 式(21)で示す 減衰装置に作用寸る水平力 $\bar{H}$ は，式(5)で示す水平力 $H$ 


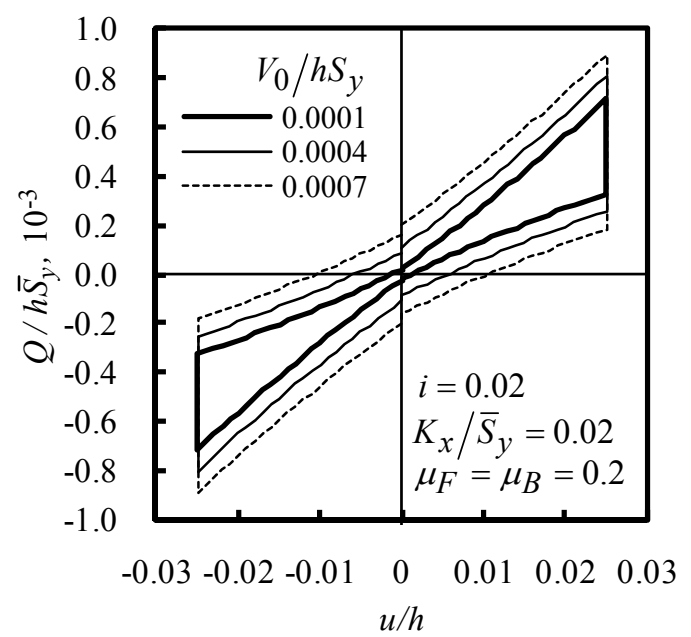

(a) 初期圧縮力による変化

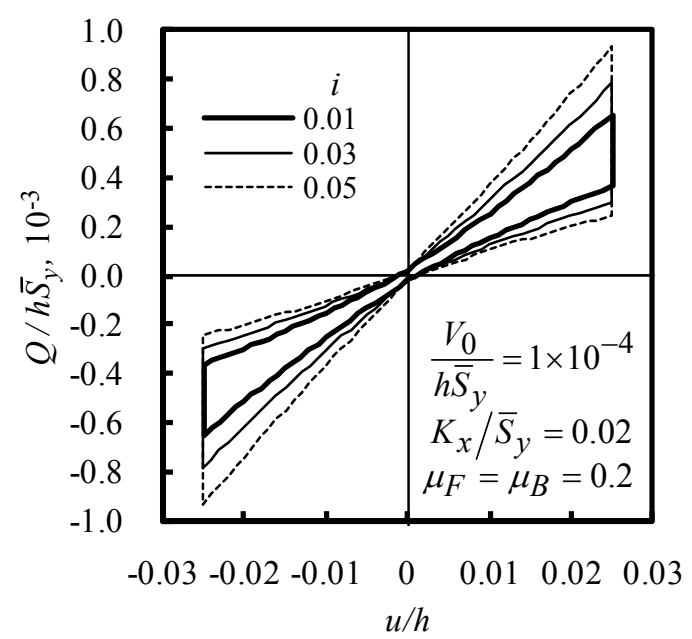

(b) 摺動面の勾配による変化

図ー11 摺動型減衰装置を装着したラーメンの水平力と水平変位の履歴曲線

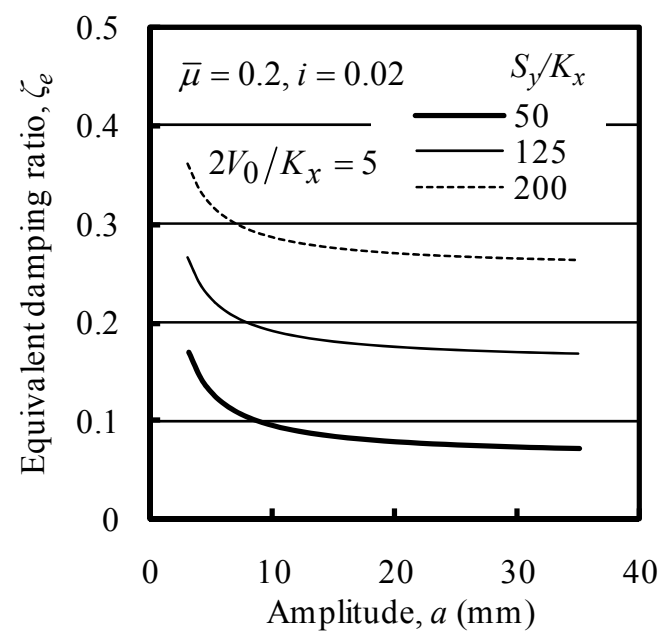

(a) ばね定数比による変化

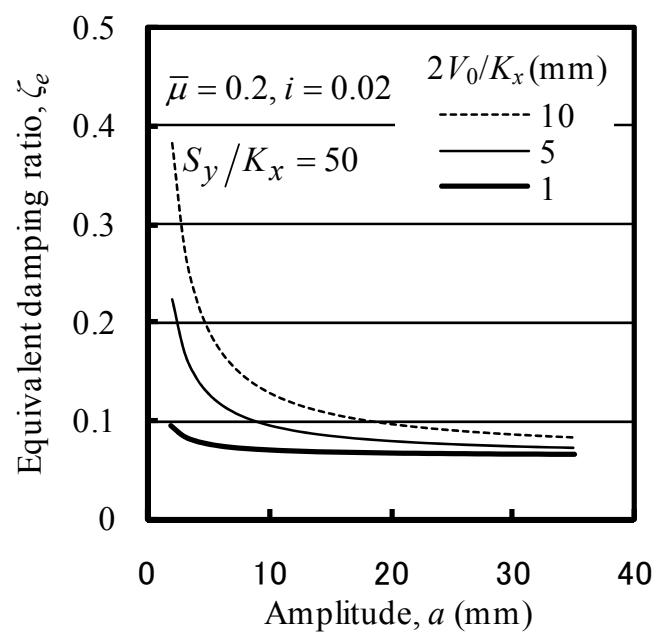

(b) 初期圧縮力による変化

図ー12 摺動装置を装着したラーメンの等価粘性減衰定数

と一致する. ラーメンの二次鉛直変位を無視し， $K_{y}$ $\gg S_{y}, 1 \pm \mu_{F} i \approx 1,1 \pm \mu_{B} i \approx 1, \quad \mu_{F}=\mu_{B}=\bar{\mu}$ の条件 を仮定すると，減衰装置を装着したラーメンの等価粘性 減衰定数 $\zeta_{e}$ は, 式(10)の等価粘性減衰係数 $c_{e}$ とラーメ ンの臨界減衰係数 $2 \sqrt{M K_{x}}$ との比として次式で定義さ れる.

$$
\zeta_{e} \equiv \frac{c_{e}}{2 \sqrt{M K_{x}}}
$$

ここに， $M$ は梁，柱の $1 / 2$, 上側壁，支持はり，U 型板 ばねおよび凸型摺動体のそれぞれの質量の合計とする.

減衰性能としては共振時の等価粘性減衰定数が重要であ るので, 式(10)の円振動数 $\theta$ は次式のラーメンの固有円 振動数 $\omega$ に置き換える.

$$
\omega=\sqrt{\frac{K_{x}}{M}}
$$

ラーメンの水平変位と凹型・凸型摺動体の摺動変位の差 は無視できる程度に小さいと考えているので, ラーメン の振幅を $a$ とすると, $a_{d} \approx a$ である. よって, 式(25)の 等価粘性減衰定数は次式となる.

$$
\zeta_{e}=\frac{\bar{\mu}}{\pi}\left(i \frac{S_{y}}{K_{x}}+\frac{2 V_{0}}{a K_{x}}\right)
$$

式(27)より，減衰装置を装着したラーメンの等価粘性減 衰定数は，摺動面の動摩擦係数と勾配，減衰装置の鉛直 ばね定数とラーメンの水平ばね定数, 初期圧縮力および ラーメンの振幅によって決まると考えられる．また，振 幅が大きくなると初期圧縮力の影響は小さくなると考え られる.

図ー12 は式(27)で計算した等価粘性減衰定数の一例 である. 図(a)と図(b)は，それぞれ摺動面の勾配と動摩 擦係数を一定とし, ばね定数比 $S_{y} / K_{x}$ と振幅 $a$ をパラ 


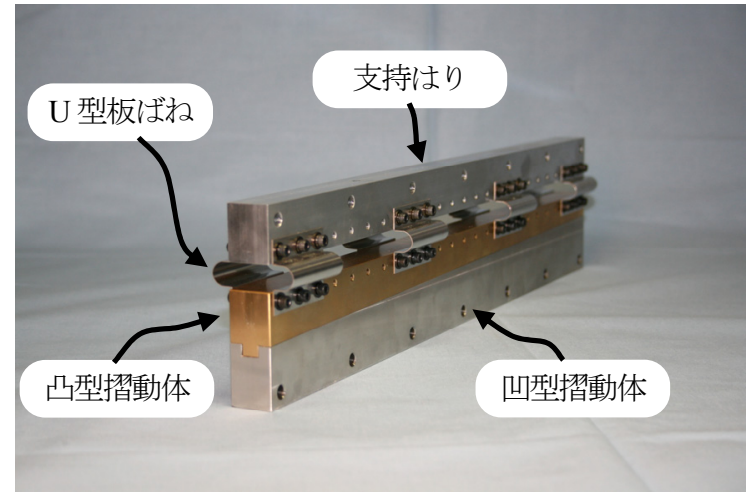

写真-1 摺動型減衰装置の外観

メータとする場合と, 初期圧縮力にかかわる $2 V_{0} / K_{x}$ と振幅 $a$ をパラメータとする場合の $\zeta_{e}$ の変化を示寸. 図(a)より， $S_{y} / K_{x}$ を大きくすることにより，減衰定数 を大きくできると考えられる．図(b)より，2 $2 V_{0} / K_{x}$ を 小さくすることにより，振幅の変化に伴う減衰定数の変 化を小さくできると考えられる。これらの図より，振幅 が大きくなると減衰定数は一定值 $\zeta_{e 0}=i \bar{\mu} S_{y} / \pi K_{x}$ に 漸近すると考えられる. また，式(27)より，動摩擦係数 と勾配を大きくすると減衰定数が大きくなると考えられ る.

以上より，一層ラーメンに提案の減衰装置を装着する 場合は，初期圧縮力を小さくすることにより等価粘性減 衰定数の振幅依存性を小さくしながら, 摺動面の動摩擦 係数，摺動面の勾配および咸衰装置の鉛直ばね定数を適 宜組み合わせることにより，ラーメンに所定の等価粘性 減衰定数で示される減衰を付加できると考えられる.

\section{4. 静的力学特性の確認実験}

\section{(1) 実験の目的}

提案の減衰装置の機能を確認するために，式(5)と式 (6a)および式(6b)で示されるローラで支持された減衰装 置の水平力と摺動変位の関係式の妥当性と, 式(24)で示 される減衰装置を装着した一層ラーメンの水平力と水平 変位の関係式の妥当性を模型実験で検証する.

\section{（2）ローラで支持された摺動型減衰装置の実験}

\section{a) 摺動型減哀装置の諸元}

写真－1 は四型摺動体，凸型摺動体，U 型板ばねおよ び支持はりで構成する提案の減衰装置の外観である。 凸 型摺動体と凹型摺動体の材料はそれぞれ快削黄銅

（C3604）とステンレス鋼（SUS304）である．摺動面 の勾配と水平長さはそれぞれ $i=0.02$ と $l_{d}=400 \mathrm{~mm}$ で ある. 組み立てられた凹型・凸型摺動体の中立時の高さ

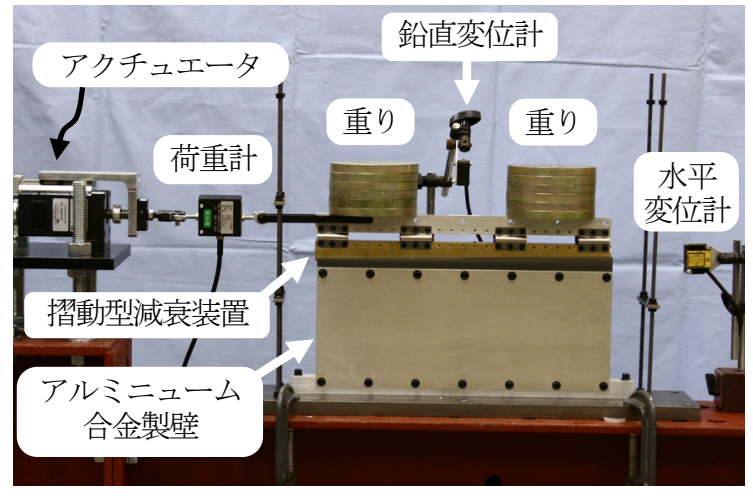

写真-2 摩擦実験装置の外観

は $h_{d}=51 \mathrm{~mm}$ である. 凹型摺動体の前方用摺動面と後 方用摺動面の幅はそれぞれ $b_{F}=5.9 \mathrm{~mm}$ と $b_{B}=8.2 \mathrm{~mm}$ である.凸型摺動体の前方用摺動面と後方用摺動面の幅 はそれぞれ $b_{F}=6.1 \mathrm{~mm}$ と $b_{B}=7.8 \mathrm{~mm}$ である. 摺動面 の機械仕上げの設計值は表面粗さ $1.6 \mu \mathrm{m} R_{a}$ 以下とし たが，仮組立の段階で前方用摺動面同士のみを擦り合わ せて, 凹型・凸型摺動体の中立位置と高さの変化を微調 整した. よって, 前方用摺動面と後方用摺動面の表面粗 さは異なると考えられたが，計測器具の問題から実際の 表面粗さは計測していない. 摺動面には動摩擦係数と静 止摩擦係数の差を小さくするためにトリクロルエタン系 の潤滑材を塗布する. 摺動面の動摩擦係数は後述する.

$\mathrm{U}$ 型板ばねの総数は 8 個とし，ばねは摺動体の両側面 にそれぞれ 4 個を配置し，ばねは凸型摺動体と支持はり を一体化する。ばねの材質はばね用ステンレス鋼帯

（SUS304-CSP）であり，各部の設計寸法は， $\varphi=0.3 \mathrm{~mm}$, $\alpha=5 \mathrm{~mm}, \beta=5.15 \mathrm{~mm}, \gamma=42 \mathrm{~mm}$ である. ばねは 1 個当た り 6 個の M3 ボルトで支持はりと凸型摺動体の側面に固 定する. 減衰装置の鈆直ばね定数は後述する. 支持はり は，高さ $\times$ 幅 $\times$ 長さ $=25 \times 20 \times 400 \mathrm{~mm}$ のアルミニュー ム合金(A6063) とした。 凸型摺動体，U 型板ばねおよ び支持はりの合計質量は $2.57 \mathrm{~kg}$ である.

\section{b) 摺動型減哀装置の動摩擦係数之高さの変化}

写真一2 は，回型・凸型摺動体の前方用摺動面と後方 用摺動面の動摩擦係数を計測する摩擦実験装置の外観で ある.アルミニューム合金製壁（A5052，t=3mm×2 枚） の上に凹型摺動体をボルトで固定し，支持はりの上に重 りを載せる．支持はりとアクチュエータを荷重計を介し て水平方向に連結し，アクチュエータを水平方向に駆動 させ，減衰装置の作動に必要な水平力を荷重計で計測す る. 荷重計の定格容量は $200 \mathrm{~N}$ である. アクチュエータ の駆動速度は $0.048 \mathrm{~mm} / \mathrm{s}$ である. また, 凸型摺動体の水 平変位と支持はりの高さの変化をレーザー変位計で計測 する. レーザー変位計の分解能は $0.002 \mathrm{~mm}$ である. 重 りの質量は $4 \mathrm{~kg}, 8 \mathrm{~kg}, 12 \mathrm{~kg}, 16 \mathrm{~kg}$ の 4 ケースとした. 


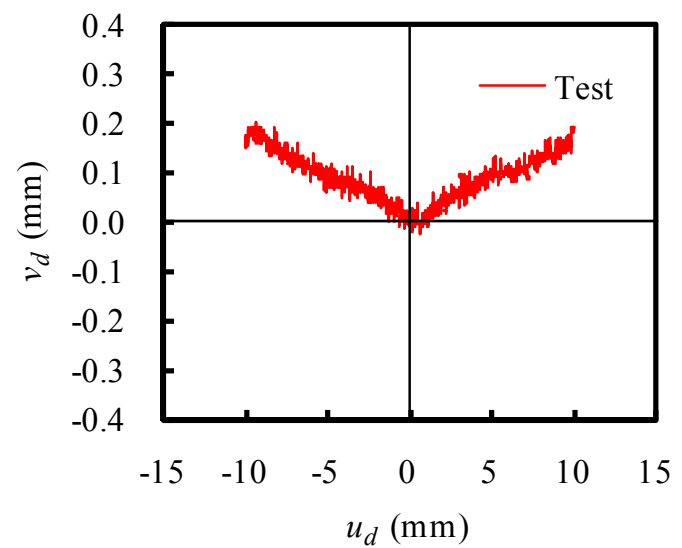

(a) 高さの変化と摺動変位

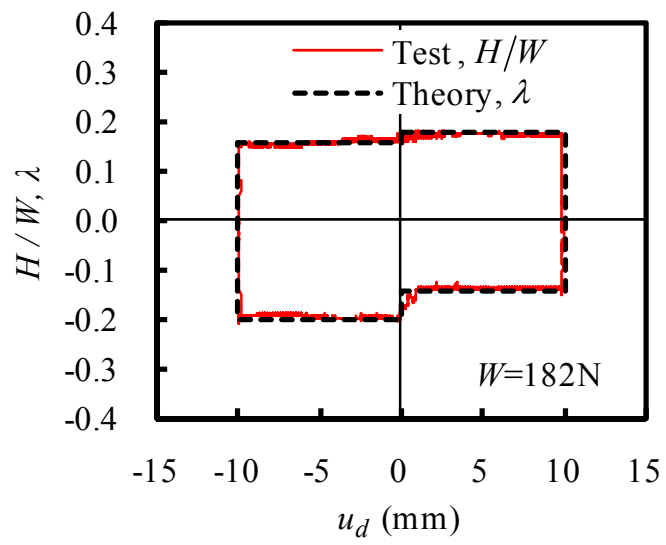

(b) 水平力と摺動変位の履歴曲線

図-13 摺動型減衰装置の高さと水平力の変化

なお, 写真中の鉛直方向の黒く細い数本の物体は, 後述 するラーメンの柱である.

図一13(a)は質量 $16 \mathrm{~kg}$ の重りを搭載した減衰装置の高 さと摺動変位の関係である.図より, 減衰装置は摺動変 位 $10 \mathrm{~mm}$ で $0.2 \mathrm{~mm}$ の高さの変化を生じるので，摺動面

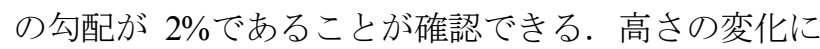
$\pm 0.05 \mathrm{~mm}$ 程度の幅が見られるが，これはアクチュエー

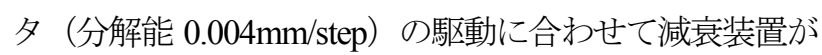
鉛直方向に振動することと，レーザー光の反射面が水平 方向に移動することにより，反射面の凹凸が測定值に影 響を及ぼしたと考えられる。

図一13(b)は質量 $16 \mathrm{~kg}$ の重りを搭載した減衰装置の水 平力と摺動変位の履歴曲線である. 水平力 $H$ は重りに よる鉛直力と初期圧縮力の合計鉛直力 $(W=182 \mathrm{~N})$ で除し て無次元化している. 水平力と鉛直力の比 $H / W$ は式 (6a) と式(6b)の運動抵抗係数に相当する. 図では, 摺動 面の動摩擦係数を $\mu_{F}=0.16, \mu_{B}=0.18$ とし, 摺動面 の勾配を $i=0.02$ とした式(6a) と式(6b)の運動抵抗係数 $\lambda$

（Theory と表記する）を併記する. 図より，実験で得 られた水平力と鉛直力の比 $H / W$ は運動抵抗係数 $\lambda$ と良 く対応することが確認される. 他の重りを軽くした場合 についても, 水平力と鉛直力の比は運動抵抗係数と良く 対応することが確認された. 前方用摺動面の動摩擦係数 が後方用摺動面のそれに比べてやや小さいが，これは前 述した仮組立時の前方用摺動面の擦り合わせ調整に関係 していると考えられる. よって，後述の実験結果の検証 に用いる前方用摺動面と後方用摺動面の動摩擦係数の実 験值はそれぞれ $\mu_{F}=0.16$ と $\mu_{B}=0.18$ とする.

\section{c) 摺動型減衰装置の鉛直ばね定数}

図-14 は，写真－2 の実験装置においてアクチュエ 一タを取り外した状態における, 重りによる鉛直力と支 持はりの鉛直変位の関係である. 図より, 減衰装置の鉛 直力と鉛直変位の関係は載荷時と除荷時共に線形である

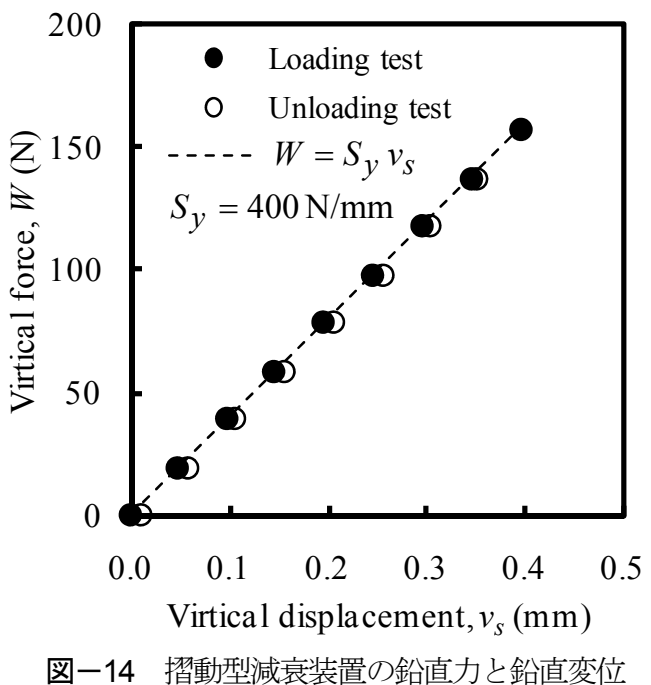

ことが確認される，実験結果から，減衰装置の鉛直ばね 定数として, $S_{y}=400 \mathrm{~N} / \mathrm{mm}$ が得られた.一方，式 (11a)と式(11b)を用いて U 型板ばね 1 個の鉛直ばね定数 を見積もると， $s_{y}=61.8 \mathrm{~N} / \mathrm{mm}$ となる. ただし，JS G 4313 に参考值として記載されているばね用ステンレス 鋼帯（SUS304-CSP）のたわみ係数 ${ }^{18)}$ をヤング係数 $E=167000 \mathrm{~N} / \mathrm{mm}^{2}$ とし $G / E$ は 0.385 とした. 上記の ばね定数の理論值を用いて, 減衰装置の鉛直ばね定数を 見積もると, $494 \mathrm{~N} / \mathrm{mm}$ となる.これを実験值 $S_{y}=$ $400 \mathrm{~N} / \mathrm{mm}$ と比較すると, 式(14)に用いる補正係数は $\psi=0.81$ となる.

\section{d) 履歴曲線}

写真-3 は，図-3 の力学モデルに対応するローラで 支持された減衰装置の実験装置の外観である，写真一2 で示した減衰装置の支持はりの上部にローラを設置し, ローラを水平方向と鉛直方向に固定された梁で鉛直方向 に支持し，変位計を介して支持はりをアクチュエータに 連結した実験装置である。ローラは直径 $20 \mathrm{~mm}$ のアル 


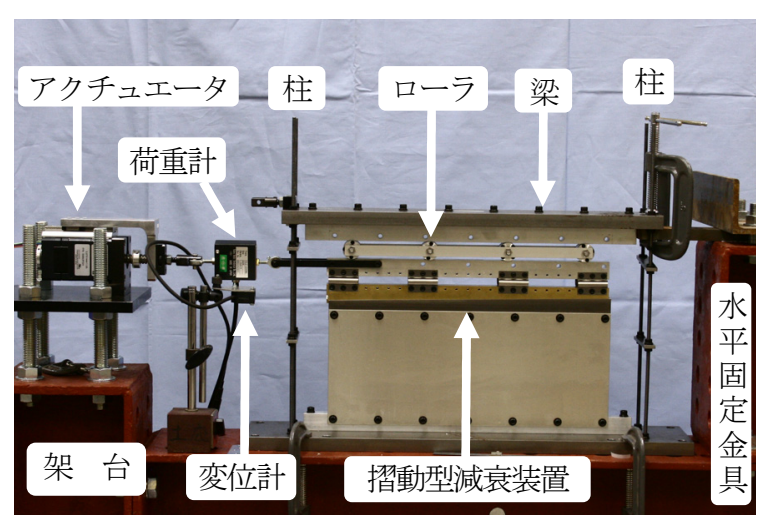

写真ー3 ローラで支持された摺動型減衰装置の外観

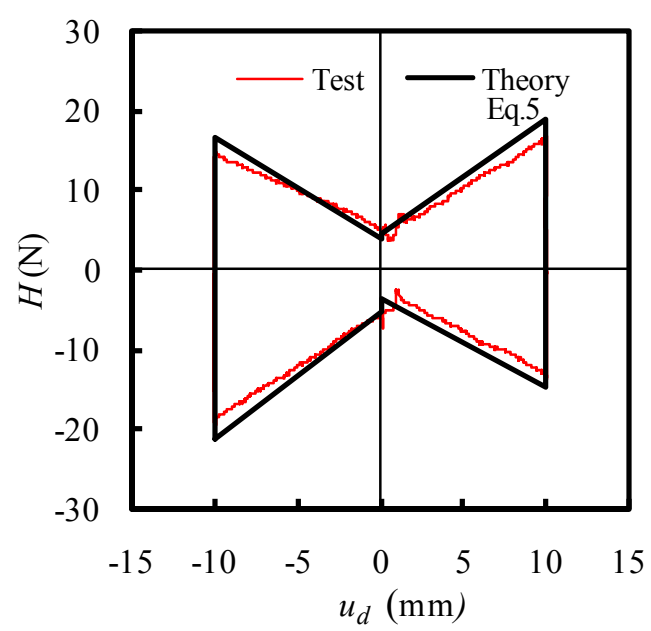

図ー15 ローラで支持された摺動型減衰装置の 水平力と摺動変位の履歴曲線の比較

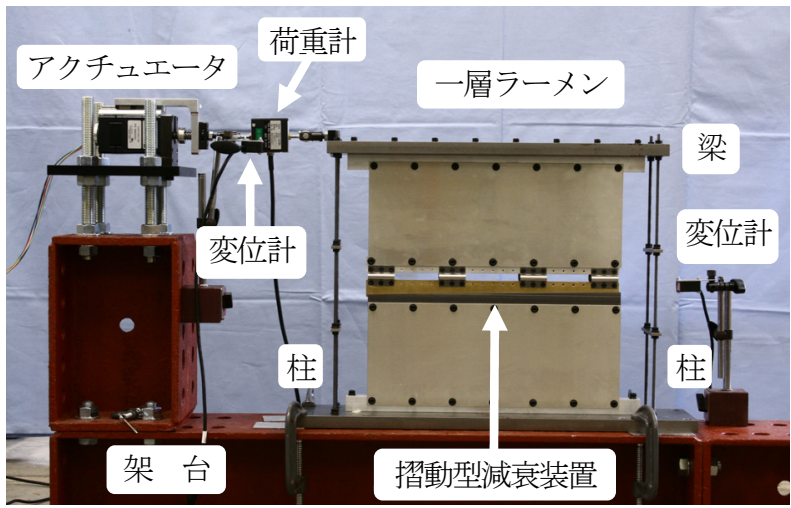

写真一4 摺動型減衰装置を装着した一層ラーメンの外観

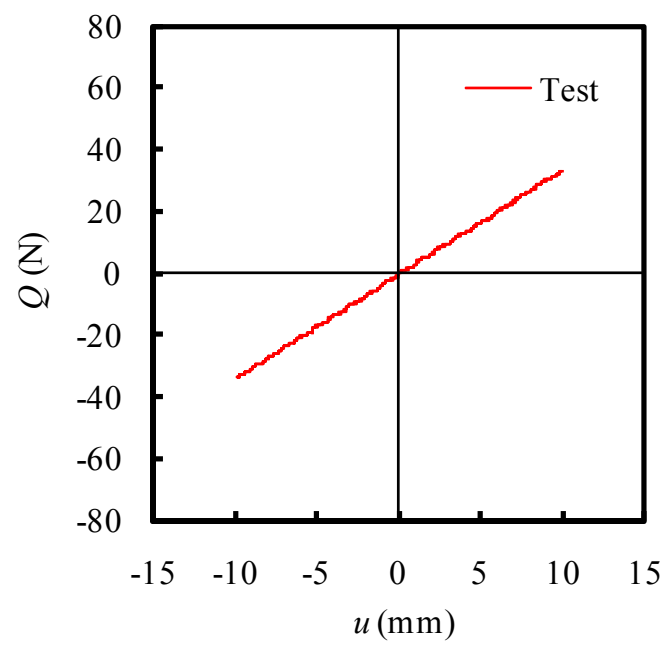

図-16 ラーメン単体の水平力と水平変位の履歴曲線
ミ製ローラとし，ローラの個数は 4 個である. 梁は 4 本 の柱で架台に連結されると共に水平方向には水平固定金 具で架台に固定されている. 柱は呼び径 M6 の鋼製ボル 卜(SS400) とし，梁は断面寸法が幅 $\times$ 高 $=100 \times 19$ のみ がき平角鋼(SS400)とした.アアクチュエータを水平方向 に駆動させ，その時の減衰装置に作用する水平力を荷重 計で計測し，凸型摺動体の水平変位を変位計で計測する

図一15 は，式(5)，式(6a)および式(6b)で示した水平力 と摺動変位の関係式で計算した履歴曲線と, 実験により 得られたそれの比較である. 初期圧縮力，鉛直ばね定数， および摺動面の勾配と摺動面の動摩擦係数はそれぞれ $V_{0}=25.2 \mathrm{~N}, S_{y}=400 \mathrm{~N} / \mathrm{mm}, i=0.02, \mu_{F}=0.16$, $\mu_{B}=0.18$ である. 初期圧縮力は, 凸型摺動体，U 型板 ばねおよび支持はりの合計質量 $2.57 \mathrm{~kg}$ と, 重力加速度 $g=9.8 \mathrm{~m} / \mathrm{s}^{2}$ より計算した. 図より, 実験值が理論值 と良く対応し，履歴曲線は蝶が羽を広げた形となること が確認される．また，実験值の履歴曲線の傾きは理論值 のそれに比べて僅かに小さくなった，これは，実験值に はローラの転がり摩擦の影響が含まれるが，理論值では
ローラの転がり摩擦を無視しているからと考えられる. なお，実験時の U 型板ばねの水平方向の変形量は小さ く, 支持はりの水平変位と凹型・凸型摺動体の摺動変位 の差は無視できる程度に小さかった.

\section{（3）摺動型減衰装置を装着した一層ラーメンの実験}

\section{a) ラーメン単体の水平力と水平変位の履歴曲線}

写真-4 は, 図-8 の力学モデルに対応する減衰装置 を装着した一層ラーメンの実験装置の外観である，写真 -3 で示した実験装置において, 梁を上方に移動させ, ローラをアルミニューム合金製壁（A5052，t $=3 \mathrm{~mm} \times 2$ 枚）に置き換えた装置である. 柱の高さと間隔はそれぞ れ $h=400 \mathrm{~mm}$ と $l=500 \mathrm{~mm}$ である. 柱と上側壁および下 側壁の隙間は $e=50 \mathrm{~mm}$ である.アルミニューム合金製 壁はボルトで支持はりと梁に固定した。 中立時の凹型・ 凸型摺動体の摺動面に凸型摺動体，U 型板ばねおよび支 持はりの自重のみが初期圧縮力として働くように，上側 壁と支持はりをボルトで連結した．よって，減衰装置に はラーメンの梁, 柱および上側壁の自重は鉛直力として 


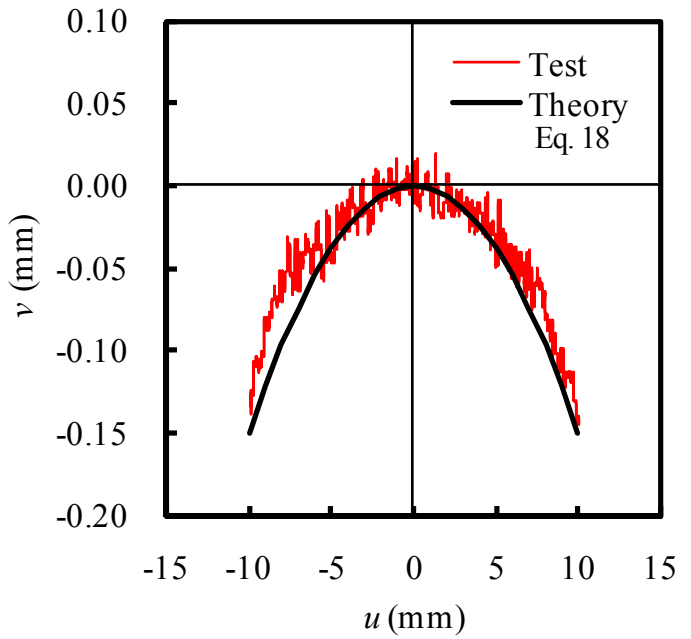

図-17 ラーメン単体の水平変位と鉛直変位

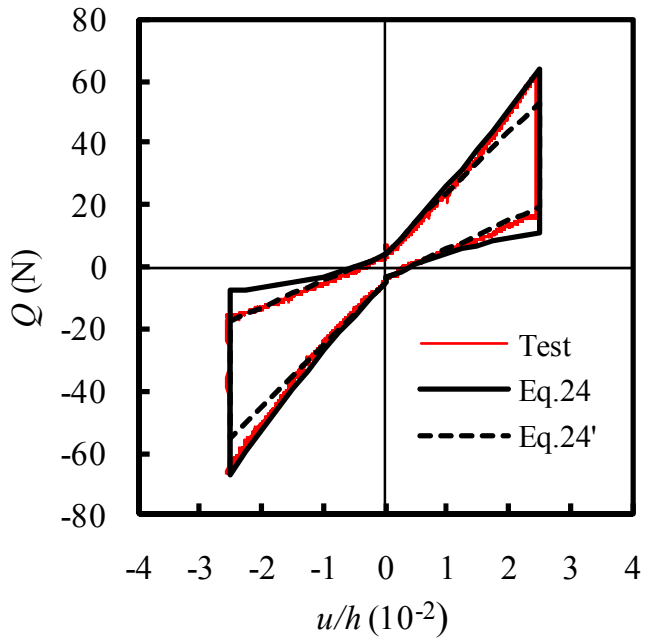

図ー18 摺動型減衰装置を装着した一層ラーメン の水平力と水平変位の履歴曲線
作用しない，荷重計を介して梁とアクチュエータを連結 し，アクチュエータを水平方向に駆動させて，梁に作用 する水平力と梁の水平変位をそれぞれ荷重計と変位計で 計測した．減衰装置の支持はりと凸型摺動体の水平変位 も計測したが，それらと梁の水平変位との差は小さく， アルミニューム合金製壁と U 型板ばねの水平方向の弾 性変形は, 摺動変位 $u_{d}$ に比べて無視できる程度に小さ かった.

図一16 は，減衰装置を取り外したラーメンの 1 サイ クルの水平力と水平変位の履歴曲線である. 履歴曲線の 載荷と除荷の経路は重なり, 水平力と水平変位の関係は 線形であることが確認される. 図に示寸実験結果より得 られたラーメンの水平ばね定数は $K_{x}=3.4 \mathrm{~N} / \mathrm{mm}$ であ る. 別途に実施した曲げ試験で得られた柱の曲げ剛性は $E_{c} I_{c} \approx 1.1 \times 10^{7} \mathrm{Nmm}^{2}$ であった. これを用いて式(23) で計算したラーメンの水平ばね定数は $4.2 \mathrm{~N} / \mathrm{mm}$ であ る. 式(23)では，柱は梁と基部に完全に固定されている と仮定しているが，柱の取付け部の弾性変形により柱の 取付け部に回転が生じ，実際の水平ばね定数は理論值よ り小さくなったと考えられる.

図ー17 は，式(18)で計算したラーメンの水平変位と 鉛直変位の関係を実験值と比較したものである. 図より, 鉛直変位は水平変位に対して放物線状に変化し，実験值 は理論值と良く対応していることが確認される.

\section{b) 摺動型減衰装置を装着した一層ラーメンの水平カと 水平変位の履歴曲線}

図一18 は，実験で得られた減衰装置を装着した一層 ラーメンの 1 サイクルの水平力と水平変位の履歴曲線と, 式(24)で計算した履歴曲線（Eq.24）および式(24)でラー メンの鉛直方向の二次鉛直変位を無視して計算した履歴 曲線（Eq.24'）の比較である。式(24)の計算条件は $i=0.02, V_{0}=25.2 \mathrm{~N}, \mu_{F}=0.16, \mu_{B}=0.18, K_{x}=$
$3.4 \mathrm{~N} / \mathrm{mm}$ ，および $S_{y}=400 \mathrm{~N} / \mathrm{mm}$ である．また，柱 の断面定数からラーメンの鉛直方向ばね定数を試算する と $K_{y} \approx 39000 \mathrm{~N} / \mathrm{mm}$ であり,$K_{y} \gg S_{y}$ となることか ら, $\bar{S}_{y} \approx S_{y}$ とした.

図一18 より，水平変位が $u / h<0.01$ の範囲では，ラ 一メンの鉛直方向の二次鉛直変位の影響は小さく，二次 鋁直変位を無視した理論值と実験值は良く対応すること が確認される. 水平変位が $u / h \geq 0.01$ の範囲では, 前方 移動・前進時と後方移動・後進時では実験值と二次鉛直 変位を考慮した理論值が良く対応しているが，前方移 動・後進時と後方移動・前進時では誤差が大きいことが 確認される.

図ー10 に示すようにラーメンと減衰装置には鉛直力 $\bar{V}$ が作用するため，この鉛直力と水平力 $(Q-\bar{H})$ によ り生じる水平変位 $u$ によって, ラーメンの柱には二次曲 げ変形が発生する．この二次曲げ変形は，水平力による 柱の曲げ変形を減少させるので，ラーメンの水平変位を 減少させると考えられる. 寸なわち，この二次曲げ変形 を考慮すると，減衰装置を装着したラーメンの水平ばね 定数は式(23)のそれよりも大きくなると考えられる.し かし，式(24)ではこの柱の二次曲げ変形の影響は考慮し ていないので，式(24)はラーメンの水平ばね定数 $K_{x}$ を 実際より小さく評価した水平力と水平変位の関係を示す と考えられる.

一方，式(18)のラーメンの二次鉛直変位は上記の柱の 二次曲げ変形の影響を考慮していないので，式(18)は柱 上端の二次鉛直変位を実際より大きく評価すると考えら れる. 結果として, 式(24)は柱上端の二次鉛直変位によ る減衰装置の摩擦力の増分を実際より大きく評価した水 平力と水平変位の関係を示寸と考えられる.

以上をまとめると，式(24)は，ラーメンの水平ば斌定 数に関しては履歴曲線の傾きを小さく評価し, 減衰装置 
の摩擦力に関しては前方移動・前進時と後方移動・後進 時には曲線の傾きを大きく評価すると共に前方移動・後 進時と後方移動・前進時には曲線の傾きを小さく評価す ると考えられる. 従って, 図一18 に示寸実験結果のよ うに，振幅が大きくなる領域において，前方移動・前進 時と後方移動・後進時では式(24) と実験值の差が小さく, 前方移動・後進時と後方移動・前進時ではそれらの差が 大きくなったと考えられる.

実用的なラーメンの水平変位は $u / h<0.01$ と考えられ るので，実用上は，二次曲げ変形を無視した式(24)にお いて，柱上端の二次鉛直变位を無視しても良いと考えら れる.

また，図ー18 より，二次鉛直変位および二次曲げ変 形を考慮しなければならない水平変位の領域を考慮して も，式(24)で二次鉛直変位を無視して計算した履歴曲線 は実験で得られた履歴曲線の内側にあり, 前者の履歴曲 線が囲む面積は後者の履歴曲線が囲む面積より小さいこ とに気づく．図の二次鉛直変位を無視した履歷曲線が囲 む面積は式(8)の散逸エネルギーに相当するので，提案 の減衰装置は式(27)で示寸等価粘性減衰定数を確保でき る可能性があると考えられる.

前方用摺動面と後方用摺動面の動摩擦係数を実験で得 られた值の平均值の $\bar{\mu}=0.17$ とし, 先に示したラーメ ンと減衰装置の諸定数を式(27)に適用すると, 次の等価 粘性減衰定数を得る.

$$
\zeta_{e}=0.127+\frac{0.802}{a}
$$

ここに, 振幅 $a$ の単位は $\mathrm{mm}$ である.これより, 実験 に用いた減衰装置を装着した一層ラーメンの共振時の等 価粘性減衰定数は, 振幅が $10 \mathrm{~mm}$ 程度の場合は 0.2 程度 であり，振幅がそれよりも大きくなる場合は 0.127 に漸 近すると予想される.

\section{5. まとめ}

本論文では，長周期の構造物に対して，小振幅から大 振幅までの振動エネルギーを効率的に吸収できる減衰装 置の開発を目的として, 減衰力としての摩擦力が変位の 絶対值に比例して増加する摺動型減衰装置を提案した. 提案の減衰装置は回型摺動体，凸型摺動体，U型板ばね および支持はりで構成する，先ず，提案の減衰装置の基 本構造を説明し, ローラで支持された減衰装置の力学モ デルを用いて摺動変位の絶対值に比例して増加寸る摩擦 力を生成する原理を説明し, 減衰装置の水平力と摺動変 位の関係式，およびその等価粘性減衰係数を導いた. 次 に，減衰装置の摺動変位が水平力が作用するラーメンの 上下間の層間水平変位と類似することに着目し，提案の
減衰装置を装着した一層ラーメンの水平力と水平変位の 関係式，およびその等価粘性減衰定数を理論的に導いた。 最後に, 減衰装置の動摩擦力特性と, ローラで支持され た減衰装置の水平力と摺動変位の履歴曲線, および減衰 装置を装着した一層ラーメンの水平力と水平変位の履歴 曲線の妥当性を具体的な模型実験で検証を行った. 本研 究で得られた知見を以下にまとめる.

a) 提案の摺動型減衰装置は, その装置の摺動変位に伴 う高さの変化を構造物内の部材などで抑制すること により, 摺動変位の絶対值に比例して増加寸る摩擦 力を生成することができる.

b) ローラで支持された摺動型減衰装置の水平力と摺動 変位の履歴曲線は理論值と実験值が良く対応し, そ の曲線の形状は蝶が羽を広げた形となる。

c) 摺動型減衰装置を装着した一層ラーメンの水平力と 水平変位の履歴曲線は理論值と実験值が良く対応し, その曲線の形状は蝶が羽を広げた形に似る。

d) 摺動面の勾配，摺動面の動摩擦係数，減衰装置の鉛 直ばね定数および初期圧縮力を適宜組み合わせるこ とにより，摺動型減衰装置の水平力と摺動変位の履 歴曲線が囲む面積を変化させることができると考え られる。

e) ローラで支持された摺動型減衰装置の水平力と摺動 変位の履歴曲線の特徵から, 摺動型減衰装置の等価 粘性減衰係数は振動数に反比例し, 振動数が小さく なると等価粘性減衰係数は大きくなると考えられる.

f) 摺動型減衰装置の初期圧縮力を小さくし, 減衰装置 が作動を開始する作動力の限界を小さくすることに より, 小振幅から大振幅まで等価粘性減衰係数をほ ぼ一定にすることが可能と考えられる.

以上より，限られた条件の小規模な模型実験の範囲内 であるが，提案の減衰装置を装着した一層ラーメンの静 的力学特性は理論值と実験值が良く対応していることか ら, 提案の減衰装置は構造物の振動を抑制する減衰装置 として機能する可能性があると考えられる. 提案の減衰 装置では減衰力が摺動変位の絶対值に比例して増加する ので, 減衰装置による振幅低減効果および咸衰力の作用 を考慮して, 構造物の構造設計を行う必要があると考え られる。減衰装置の $U$ 型板ばねが塑性を示寸作動限界 および減衰装置の最大作動変位は，構造物の塑性変形性 能を考慮した而震設計で決定寸る必要があると考えられ る.

また，減衰装置の外力の作用に対する変形様式から， 提案の減衰装置はせん断力部材型の減衰装置と考えられ るが，凹型摺動体，凸型摺動体，U型板ばねおよび支持 はりの個数や配置を工夫することにより，軸力部材型の 減衰装置一の拡張も可能と考えられる.

なお，提案の減衰装置の有効性については，振動実験 
などにより具体的に減衰性能を検証する必要があると考 えられる。

\section{参考文献}

1) 土木学会・日本建築学会 : 海溝型巨大地震による長周期 地震動と土木・建築構造物の而震性向上に関する共同提 言, 2006 .

2) Soong, T. T. and Constantinou, M. C.: Passive and Active Structural Vibration Control in Civil Engineering, SpringerVerlag Wien-New York, Italy, pp.209-221, 1994.

3) 鈴木浩平 : ダンピングと制振の技術一制振材料と新しい ダンパの開発一, 計測と制御, 第 37 巻, 第 8 号, pp.531-540, 1998.

4）有馬文昭，井上豊，馬場研介，黒田英二 : 増幅機構付き 減衰装置の開発（その1.ボール秃じを用いた制震チュー ブの減衰特性）, 日本建築学会大会学術講演梗概集, pp.825-826, 1998.9.

5) 中南滋樹, 鈴木亨, 古橋剛, 光阪勇治, 田中久也 : 増幅 機構付き減衰装置の動的高速試験, 三井住友建設技術研究 所報告, 第 1 号, pp.89-94, 2003.

6) 日本鋼構造協会 : 履歴型ダンパー付骨組みの地震応答性 状と而震設計法, 日本鋼構造協会, 1998.

7) 宇佐美勉，加藤基規，葛西明：制震ダンパーとしての座 屈拘束ブレースの要求性能, 構造工学論文集, Vol.50A, pp.527-538, 2004.

8）宇佐美勉，葛漢涁，日沖堅治，路志浩，河野豪 : 制震ダ ンパーによる鋼アーチ橋の耐震性向上一橋軸直角方向地
震動に対する検討，土木学会論文集，No.766/I-68，pp.245$261,2004$.

9) 森下邦宏, 平井潤, 本田誠, 井上幸一: 複数摺動面を有 する摩擦型ダンパーの実験的研究, 日本建築学会構造系 論文集，第 574 号, pp.61-68, 2003.

10）寺井雅和，佐藤孝典，吉岡智和，南宏一 : ゴムワッシヤ 一を用いた高力ボルト摩擦すべりダンパーに関する研究, 日本建築学会構造系論文集，第614 号,pp.107-114, 2007.

11）寺井雅和，佐藤孝典，吉岡智和，南宏一：アルミを挟ん だ風地震ハイブリット摩擦ダンパーに関する研究, 日本 建築学会構造系論文集，第 633 号,pp.2037-2044, 2008.

12) Clough, R. W. and Penzien, J.: Dynamics of Structures, McGrawHill, Inc., USA, pp.76-77, 1975.

13) Tradjbakhsh, I. and Lin, B. C.: Displacement-Proportional Friction (DPF) in Base Isolation, Earthquake Engineering and Structural Dynamics, Vol. 15, John Wiley \& Sons, Ltd., pp.799813, 1987.

14）若林信宏, 大亦絢一郎, 斎藤宏和 : 漸硬形抵抗力特性を 有する摩擦ダンパの研究，日本機械学会論文集（C 編）, 73 巻 732 号, pp.15-22, 2007.

15）ばね技術研究会：ばね，pp.253-256，丸善， 1970.

16）倉持道夫：輪ばねを用いた建造物の耐振補強装置，特許 第 2784888 号, 1998.

17) 中原一郎 : 材料力学 (上巻) , pp.213-214, 養賢堂, 1965.

18）日本工業規格：ばね用ステンレス鋼帯，JIS G 4313，1996。

(2010. 4. 19 受付)

\title{
ANALYTICAL AND EXPERIMENTAL STUDIES OF A RUBBING DAMPER DEVICE WHICH GENERATES FRICTIONAL FORCE IN PROPORTION TO ABSOLUTE RUBBING DISPLACEMENT
}

\author{
Takuro KATAYAMA and Toshitaka YAMAO
}

In this paper, a rubbing damper device, generating frictional force in proportion to absolute rubbing displacement, is proposed in order to aid passive vibration control of frame structures. The proposed rubbing damper device is composed of a rubbing pair of concave bar and convex bar which is connected to a supported beam (which is usually fixed to object) by U-type leaf springs. Two parallel ascent interfaces and a descent interface of the rubbing pair increase assembled height of the rubbing pair in proportion to the absolute rubbing displacement of the rubbing damper device respectively. The U-type leaf springs are compressed by the rubbing pair and the supported beam, and apply compression force to the rubbing pair. Therefore, the rubbing damper device generates frictional force as damping force on the two parallel ascent interfaces or the desent interface due to the above compression force. Firstly, a basic function of the rubbing damper device and its mechanical principle are described theoretically. Then force versus displacement hysteretic curves of the rubbing damper device and a simple rigid test frame with the rubbing damper device are obtained. Finally, the hysteretic curves of the rubbing damper device and the simple rigid test frame are investigated experimentally. 